\title{
Passive Immunity Should and Will Work for COVID-19 for Some Patients
}

\author{
Nevio Cimolai ${ }^{1,2 *}$, (D) \\ ${ }^{1}$ Faculty of Medicine, The University of British Columbia, Vancouver, BC, Canada \\ ${ }^{2}$ Department of Pathology and Laboratory Medicine, Children's and Women's Health Centre of British Columbia, 4480 Oak Street, \\ Vancouver, BC, Canada V6H 3 V4
}

\section{ARTICLE INFO}

\section{Article History}

Received 23 January 2021

Accepted 02 March 2021

Keywords

COVID-19

coronavirus

plasma

antibody

immunity

\begin{abstract}
In the absence of effective antiviral chemotherapy and still in the context of emerging vaccines for severe acute respiratory syndrome-CoV-2 infections, passive immunotherapy remains a key treatment and possible prevention strategy. What might initially be conceived as a simplified donor-recipient process, the intricacies of donor plasma, IV immunoglobulins, and monoclonal antibody modality applications are becoming more apparent. Key targets of such treatment have largely focused on virus neutralization and the specific viral components of the attachment Spike protein and its constituents (e.g., receptor binding domain, $\mathrm{N}$-terminal domain). The cumulative laboratory and clinical experience suggests that beneficial protective and treatment outcomes are possible. Both a dose- and a time-dependency emerge. Lesser understood are the concepts of bioavailability and distribution. Apart from direct antigen binding from protective immunoglobulins, antibody effector functions have potential roles in outcome. In attempting to mimic the natural but variable response to infection or vaccination, a strong functional polyclonal approach attracts the potential benefits of attacking antigen diversity, high antibody avidity, antibody persistence, and protection against escape viral mutation. The availability and ease of administration for any passive immunotherapy product must be considered in the current climate of need. There is never a perfect product, but yet there is considerable room for improving patient outcomes. Given the variability of human genetics, immunity, and disease, and given the nuances of the virus and its potential for change, passive immunotherapy can be developed that will be effective for some but not all patients. An understanding of such patient variability and limitations is just as important as the understanding of the direct interactions between immunotherapy and virus.
\end{abstract}

(C) 2021 International Academy for Clinical Hematology. Publishing services by Atlantis Press International B.V This is an open access article distributed under the CC BY-NC 4.0 license (http://creativecommons.org/licenses/by-nc/4.0/).

\section{INTRODUCTION}

Interest in passive immune therapy for the treatment of infectious diseases has long existed [1-3]. There have been many examples of application for either prevention or active treatment, but variable efficacies occur in the many scenarios in which such treatment has been applied. During the epidemic of severe acute respiratory syndrome (SARS), equivalent approaches were resurrected, but largely thereafter abandoned, as the SARS prevalence came to a conclusive end in a relatively short period of time. Contemporary but meagre progress had been made in response to the Middle East Respiratory Syndrome (MERS), but the COVID-19 pandemic has again rekindled considerable interest. Indeed, a recent large randomized placebo-controlled trial of convalescent plasma infusion was conducted in which there was a lack of efficacy for severely ill patients on either clinical status or mortality; that analysis has reminded the medical and scientific communities to approach any such therapy with due diligence [4]. The lack of obvious effective antiviral therapy continues to be a source of frustration despite the advent of several seemingly effective vaccines. As vaccine distribution widens and long-term vaccine efficacy continues to

Email:ncimolai@mail.ubc.ca

Peer review under responsibility of the International Academy for Clinical Hematology be gauged, active treatment of COVID-19 is yet in need of other preventive or treatment strategies. In the context of the publication of Simonovich et al. [4] and its implications to passive therapy for SARS-CoV-2 infections, this review examines the promise, application, and future of passive immunotherapy.

\section{LESSONS FROM COMPARATIVE CORONAVIROLOGY}

Preceding or shortly following SARS and apart from MERS, and COVID-19, several coronaviruses were found to cause human respiratory illnesses and less common complications [5]. None of these four virus (OC43, 229E, NL63, HKU1) infections were effectively studied for passive immunotherapy or vaccination, but it was shown at least for some that serum neutralizing or respiratory antibody presence correlated with protection [6]. Similar themes on protection were also evident through experimentation or natural infection with animal respiratory or enteric coronaviruses [7]. For the latter, passive immunotherapy proved effective, and this was especially typified by the understanding of protective antibody transfer from mother to offspring [7]. Table 1 highlights some key findings in passive immunity for these coronaviruses which have relevance to similar efforts for SARS-CoV-2 infections [8,9]. Passive 
Table 1 Key translational findings in studies of passive immunity for human endemic respiratory coronavirus, SARS-CoV-1, and MERS infections

\begin{tabular}{lcc}
\hline References & Model system & Treatment \\
\hline Human endemic respiratory coronavirus infections \\
{$[8]$} & $\begin{array}{rc}\text { Human experimental } \\
\text { infection with 229E }\end{array}$ & $\begin{array}{c}\text { None; volunteers examined for } \\
\text { preceding immunity }\end{array}$ \\
& $\begin{array}{r}\text { Human experimental } \\
\text { infection with 229E }\end{array}$ & None; repeat infections after 1 year
\end{tabular}

$\begin{array}{ll}\begin{array}{l}\text { SARS-CoV-1 infection } \\ {[10]}\end{array} & \begin{array}{l}\text { Murine } \\ {[11]}\end{array} \\ {[12]} & \text { Murine } \\ {[13]} & \text { Human } \\ {[14]} & \text { Human }\end{array}$

MERS infection

$\begin{array}{ll}{[15]} & \text { Murine } \\ {[16]} & \text { Murine } \\ {[17]} & \text { Murine } \\ {[18]} & \text { Murine } \\ {[19]} & \text { Murine } \\ {[20]} & \text { Murine } \\ {[21]} & \text { Marmoset } \\ {[22]} & \text { Marmoset }\end{array}$

Post-infectious serum given intraperitoneal; equivalent to $700-1750 \mathrm{~mL} / 70 \mathrm{~kg}$ person

Neutralizing human MAb given intraperitoneal; $4-80 \mathrm{mg} / \mathrm{kg}$

Engineered human MAb given intraperitoneal; $200 \mathrm{mcg}$

Convalescent plasma 1:160-1:2560 'antibody titre' given in dose of 200-400 mL intravenous

Convalescent plasma 1:160-1:2560 'antibody titre' given in dose of 160-640 $\mathrm{mL}$ intravenous 9-22 days

Humanized murine MAb given intravenous $10 \mathrm{mg} / \mathrm{kg}$

Humanized murine MAb given intravenous $2 \mathrm{mg} / \mathrm{kg}$

Human MAb given intraperitoneal; 1-200 mcg

Chicken IgY given intraperitoneal 500 mcg twice

Equine serum (200 mcL), equine IgG (500 mcg), or $\mathrm{F}\left(\mathrm{ab}^{\prime}\right)_{2}(500 \mathrm{mcg})$ given intraperitoneal

Human convalescent serum (100 mcL titre $>1: 5000)$ or human MAb (20 mcg) given intraperitoneal four times

Human MAb given intravenously; $10-25 \mathrm{mg} / \mathrm{kg}$

Hyperimmune marmoset plasma $(1 \mathrm{~mL}$; titre 1:3840) or single human MAb (5 mg) given intravenously early after infection and repeated subcutaneously later
Outcomes

Viral challenge modulated by previous immunity; both circulating and local antibody were associated with protection Intranasal infection protects against repeat nasal challenge; post-infection antibody wanes; those primarily challenged but not seemingly infected maintained secondary challenge reduction in illness

Reduced lung titres of virus post-challenge; dose-responsiveness

Reduced lung titres of virus post-challenge and reduced histopathology of disease

Prevented and mitigated infection

Reduced hospital stay and mortality (note: method of antibody assessment not mentioned)

Trend for reduced mortality and reduction in some disease parameters; timing-dependent (note: method of antibody assessment not mentioned)

Reduced lung titres of virus and lung disease

Reduced lung disease and mortality

Reduced lung titres or virus and lung disease two MAb were superior to any one

Given after onset of infection and improved some infection parameters

Reduced lung titres of virus

Reduced viral load in lungs and improved survival

Effected prevention more than treatment of active infection

Both decreased signs of disease but only plasma reduced viral load

MAb, monoclonal antibody.

immunity has potential for protection and treatment, but there is usually a dose- and time-dependent effect. This is applicable to convalescent plasma, hyperimmune serum, purified immunoglobulin, or monoclonal antibodies. Different monoclonal antibodies behave variably but are more often better active in combinations.

There has been considerable debate over the role of human endemic respiratory coronaviruses for providing some protection for SARSCoV-2 infections [23-27]. The finding of common and conserved epitopes initially provided the stimulus, but a more precise analysis of antibody evolution and cell-mediated immune reactivity led to further insight. Neutralizing cross-reactive antibodies between these viruses and SARS-CoV-2 are generally lacking in humans, and yet there are some pan-coronavirus cross-reactive epitopes [26-28]. Dugas et al. [29] have found evidence suggesting a lesser severe disease with COVID-19 if patients possessed higher levels of antibodies to the endemic coronaviruses. Others found a rise in antibody levels to endemic respiratory coronaviruses during SARS-CoV-2 infection [30]. Also, immunity from other coronavirus infections might protect against COVID-19 over time, and susceptibility to serious infection appears to be age-accrued. These issues may be explained in part by differences in $\mathrm{T}$ cell responses and background humoral immunity [31].

\section{COVID-19}

\subsection{Immunogens and Humoral Immunity}

Characterization of viral immunoreactive epitopes is becoming more apparent as virus-directed antigens are being better characterized [32]. The tools for any such characterization were largely available prior to the onset of the pandemic, and further progress often relies on the application of past knowledge to the context of SARS-CoV-2.

The Spike (S) protein is a dominant immunoreactive protein and has several recognized regions, including the receptor binding domain [33-39]. Other recognized antigens commonly include Nucleocapsid (N), Membrane (M), orf3a, orf6, orf8, orf10, and 
Nsp5 (Mpro or 3CLpro) (Figure 1) [36,37,39-44]. The latter may or may not include structural proteins of intact virus and may arise as proteins derived during the processes of infection. There are potentially several more virus-directed proteins that may attract humoral responses [40]. Some of the latter appear to be shared with common non-SARS-CoV-2 coronaviruses [34,45]. For unknown reasons, the Envelope (E) protein which is virus surface-exposed does not attract humoral immune reactivity very well [46]. Antigen-specific antibody responses can vary, and stereotypic de novo responses occur [34,35,37,47-49]. An immunodominance of anti-Receptor Binding Domain (RBD) in the neutralizing antibody profile has been proposed $[33,50]$. Others found a lesser dominance in antiRBD [34,48]. Smits et al. [44] suggest that the N protein is immunodominant. Recognition of immunogenic proteins or other structures is yet provisional.

Whether for enzyme immunoassay-detected antibody (or similar) or neutralizing antibody, the total specific antibody level peaks after 3-10 weeks [30,51-60]. As anticipated, IgM reactivity diminishes over the first few months while IgG reactivity continues to be detected for a much longer interval [54,56,57,59,61-67]. The finding of rapid IgG response relative to IgM suggests a possible priming from past exposure to endemic respiratory coronaviruses [34]. Circulating IgA responses generally parallel those of IgG although not as prolonged $[56,62,64,65,68-70]$. One study found considerable IgA titres associated with severe respiratory disease [71]. Others have found no consistent IgG/IgA correlation for intensity of production [34]. Quantitation by most methods increase with the severity of infection [33,34,36,41,50,52,56,60,70-87]. Severe disease may be associated with a delay of the humoral response [88]. Children with multisystem inflammatory syndrome amount stronger antibody responses akin to more severely ill adults, and

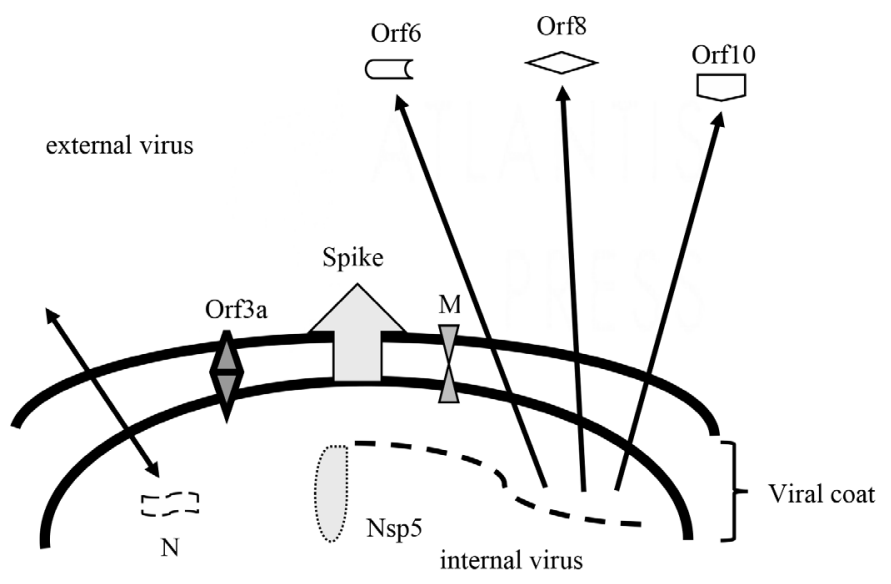

Figure 1 Provisional structural and non-structural immunogens of SARS-CoV-2. N, nucleocapsid protein functions in virus packaging and transcription complex; Nsp5, non-structural protein 5 also referred to as main protease [Mpro or 3CLpro] functions to process several virus proteins; $\mathrm{M}$, membrane protein functions to promote intracellular virus assembly; Spike, spike protein including RBD functions in virus attachment and entry; Orf3a, open reading frame protein $3 \mathrm{a}$ functions as an ion channel and promoter of virus budding; Orf6, open reading frame protein 6 functions in cellular and extracellular immunomodulation; Orf 8 , open reading frame protein 8 functions in cellular and extracellular immunomodulation; Orf10, open reading frame protein 10 possibly functions in cellular immunomodulation but its role is controversial if any. in contrast to either children or adults with mild illness [89]. A greater quantitation of antibody at the time of disease presentation may be associated with lesser mortality [30,90]. Others have found little difference of IgG reactivity to S protein among moderate to severe infections [88,91]. Affinity maturation is time accrued $[50,78]$. A small proportion do not seroconvert after infection, and thus not all post-infectious sera may be useful, even though other aspects of post-infection immunity via cell-mediated immunity may have arisen in these patients [33,34,68,72-74,77,92-94]. A lack of antibody response is particularly noticeable for asymptomatic and out-patients $[33,64,68,73,77,85,89,95]$. Using a given threshold of anti-RBD antibody, Bartsch et al. [89] define a limit above which other immune responses and effector functions are recruited. Immunocompromise may also be a risk factor for lack of antibody production $[96,97]$. A portion of the latter patients may not develop IgG or neutralizing antibodies $[34,35,95]$. Variation in antibody production among different ethnicities, but not gender, is consistent with the genetic variation that would be anticipated $[52,64,77,92]$. Other authors provide evidence for a gender difference $[35,58,76,80,82,86]$. Patients with older age also appear to have higher antibody quantities, although they are also at risk for more severe infections $[35,36,72,79,80,82,83]$. Some authors have not found an age-related variance [52,64,81]. Dyssynchronous adaptive immunity may be associated with a propensity to worse disease $[98,99]$.

Different antibody responses decay variably and dependent on the nature of the antibody target and severity of disease $[33,50,54,59,61,68,75,76,78,83,87,95,96,100-103]$. The latter includes measurable neutralizing antibody, and the decay in some patients after 1 month can be such that donations with desirable high titres elapse quickly in convalescence after infection [49,54,103-106]. Neutralization antibodies may decline although maturation in Fc effector functions may persist [66]. Key antibody responses are followed by memory B cell persistence [28,39,48,49, $57,65,66,78,102,107]$. Likewise, $\mathrm{T}$ cell recognition lasts well after declining humoral immunity markers $[23,57,67]$. The memory B potential increases with severity of infection [39]. Some groups have found a degree of anti-S2 subunit and anti-N IgG reactivity in infection-naïve individuals $[45,107]$. Gaebler et al. [78] have proposed that antibody maturation may be a function of prolonged antigenic exposure. Binding affinity to $S$ is time accrued [28].

\subsection{Correlations with Immunity or Protection}

$\mathrm{T}$ cell immunity arises, as anticipated, during infection, and the quality and quantity of the same varies according to the intensity of disease. [31,48,51,63,65,67,68,70,74,89,91,93,94,98,102,109-111]. As passive immunotherapy is conventionally ascribed to immunoglobulins in a cell-free product, the translocation of such preformed cell-mediated immunity cannot be accomplished apart from immunoglobulin-related effector functions. Even if cellmediated immunity could conceivably be 'donated' with alternate allogeneic blood products or stem cells, the prospect of complex incompatibility immune reactions would complicate usage. It may also be that preceding low-avidity $\mathrm{T}$ cell responses may commonly exist among humans, and that post-infection $\mathrm{T}$ cell responses may vary also in such avidity, according to disease intensity [94,109]. 
Mild infections may nevertheless attract memory $\mathrm{T}$ cell presence $[23,65,102]$. In a rhesus macaque model, CD8+ T cells may have a functional role even when circulating specific antibody levels are low [112]. These findings are consistent with the proposal that good quality humoral and cell-mediated responses may require a particular intensity of disease, such that the immune system must cross a particular barrier after which quality and prolongation arise [89]. Immunosuppression in animal models facilitates more virulent infection [113]. Cohen et al. [31] portray a scenario where differential $\mathrm{T}$ cell responses give rise to varying disease susceptibility for young and older ages. The latter is also supported by other age-related differences shown for $\mathrm{B}$ and $\mathrm{T}$ cell clonal expansions after infection [114]. These variations on age-related responses may also be superimposed on the differential character of innate immune reactivity [115].

In other systems, the contributions of both neutralizing and immunoglobulin effector functions may be relevant to the persistence of protective antiviral immunity $[89,116]$. That a humoral immune response occurs does not necessarily imply that such reactivity has mature effector functions [34,99]. Effector function variability in donor plasma samples is considerable [34]. Antibody effector functions can be Fc-mediated and may include such entities as antibody-dependent natural killer cell activation and degranulation, antibody-dependent cellular phagocytosis by monocytes and neutrophils, antibody-mediated complement deposition, Fc-mediated macrophage polarization, antigen presentation, and $\mathrm{B}$ cell activation.

There are many potential approaches to detecting neutralizing antibodies, and there are many more variations that are technically possible (Table 2) [117-119]. It is more critical to establish correlates of any such neutralization with actual protection or treatment because of potential concerns over veritable markers for the latter [118]. Whereas correlations between neutralizing antibody measures are generally good, there are nevertheless important subtle differences, and some measures may consistently show higher surrogate neutralization titres than more conventional and historic assays [119]. The presence of neutralizing antibodies as measured by pseudo-typed lentivirus particles correlated with protection [120]. It is not clear if pan-coronavirus antigen reactivity correlates with protection even though it may be associated with neutralization [45]. Lv et al. [121] proposed that SARS-CoV-1 and SARS-CoV-2 may have cross-reactive antibody to the $S$ protein but not necessarily cross-neutralizing antibody. From studies with human monoclonal antibodies, it is apparent that in vitro measures of neutralization do not always correlate with in vivo efficacy of relative potency [122].

The presence of anti-viral IgM can correlate with neutralization potential [34]. Klingler et al. [123] suggest that IgM and IgG1 contribute considerably to neutralization and lesser so for IgA. In developing mucosal IgA, the circulating serum antibody does not necessarily have to be robust [71]. Dimeric mucosal IgA has greater potency to neutralize than monomeric IgA [69]. There is a general trend for an association of seropositivity with a lesser opportunity for apparent repeat infections over time, although these are preliminary observations [124]. Shields et al. [125] found a pre-vaccination high seroprevalence of anti-S antibody among dental professionals. A particular IgG EIA threshold was found to correlate with protection against subsequent infection and seropositivity was retained for many months.

Anti-S antibody levels correlate well with those of neutralizing antibodies, including anti-RBD [30,33,38,48,62,64,81,86,88,90,106, 126-132]. Piccoli et al. [50] have proposed that some $90 \%$ of neutralizing activity is due to anti-RBD antibody, and they have particularly mapped two dominant subepitopes. Wendel et al. [105] found good correlation of anti-N antibody and neutralization. Among convalescent plasma from a voluntary donor program, a correlation was found for high IgG anti-N titres and neutralization titres $\geq 1 / 160$ [105]. Another study found that both moderate and high EIA anti-N antibody correlate with neutralization titres $>1: 80$ [43]. Others found a modest correlation of anti-S1 antibody as detected with a commercial EIA to neutralization titres $>1: 100$ [133]. Salazar et al. [33,129] found a better correlation between anti-RBD response and neutralization titres in convalescent patient samples. Bryan et al. [134] determined that the presence of anti-N IgG correlated with a reduction in 30-day mortality. Secchi et al. [37] found a correlation of anti-RBD IgG with survival. Antibody avidity matures after infection and is correlated with duration of infection and higher neutralizing antibodies $[28,135]$. The avidity

Table 2 Key methods for determining SARS-CoV-2 neutralizing antibody

\begin{tabular}{|c|c|c|}
\hline Methods & Approach & Methodological nuances \\
\hline $\begin{array}{l}\text { Live virus neutralization } \\
\text { Cytopathic effect } \\
\text { Plaque-reduction } \\
\text { Focus-reduction }\end{array}$ & $\begin{array}{l}\text { Live virus pre-admixed with patient serum } \\
\text { dilutions is applied to viable cell line }\end{array}$ & $\begin{array}{l}\text { Cell line susceptibility variable; different reporter systems possible } \\
\text { for measuring virus infection; requires viable SARS-CoV-2 with } \\
\text { inherent biosafety issues; non-cytopathic effect reporter systems } \\
\text { possible facilitating through-put; lesser susceptible cell lines } \\
\text { can be transduced with ACE2 or TMPRSS2 receptors to } \\
\text { enhance assay }\end{array}$ \\
\hline $\begin{array}{l}\text { Pseudo-type neutralization } \\
\text { Vesicular stomatitis virus } \\
\text { Lentivirus } \\
\text { Murine leukemia virus } \\
\text { HIV-1 }\end{array}$ & $\begin{array}{l}\text { Alternate virus with SARS-CoV-2 antigen is } \\
\text { pre-admixed with patient serum and applied to } \\
\text { detector cell line; reporter signal detected variably }\end{array}$ & $\begin{array}{l}\text { Non-infectious for SARS-CoV-2 thus avoiding many biosafety } \\
\text { concerns; detector cell lines can be transformed to enhance } \\
\text { assay; many potential forms of detector signals; high through- } \\
\text { put possibilities }\end{array}$ \\
\hline Surrogate neutralization & $\begin{array}{l}\text { SARS-CoV-2 attachment protein-bound surrogate } \\
\text { is directly pre-mixed with patient serum or } \\
\text { assessed in a competitive immunoassay; } \\
\text { reporter signal can vary }\end{array}$ & $\begin{array}{l}\text { Non-viral surrogate approach markedly lessens biosafety concerns; } \\
\text { attachment protein can have various conformations or lengths; } \\
\text { very amenable to high through-put; attachment nullification } \\
\text { simplifies concept of neutralization whereas live virus method } \\
\text { may be assessing multi-modal virus attachment and non- } \\
\text { attachment inhibitions }\end{array}$ \\
\hline
\end{tabular}


of anti-S correlates better than anti-N. Li et al. [36] found an association of low IgG anti-S, anti-RBD, and anti-N with a longer duration of viral RNA shedding. Antibody mapping has the potential to further define relevant antigens [136-138]. Microarrays offer a more complex mechanism to define immunoreactive epitopes even when honed down to a few larger but common antigens such as $\mathrm{S}$ and $\mathrm{N}$ proteins $[42,139]$. Neutralizing antibody levels may also correlate well with particular adaptive T cell responses [111].

\subsection{The Potential Perils of Neutralization Escape}

The D614G mutation in the S protein did not associate with neutralization escape $[39,63,73]$. Variant mutations of concern have recently included at least UK B.1.1.7, South Africa B.1.351, and Brazil B.1.1.28.1 [140-150]. Other groups have more recently shown that escape mutants are time accrued in tissue culture or animal models, have particular mutations, and may completely escape neutralization $[150,151]$. Such mutants may develop over the course of an infection [152]. Mutants can potentially escape neutralization by some but not other convalescent sera, and it is thus evident that an individual's repertoire of antibody production should be identified; this would have bearing on the use of single donor plasma donations and their variable efficacy [153-156]. It may also be possible that the exposure to donor antibody may select further for viral mutants [157]. Likewise, resistance to therapeutic monoclonal antibodies may also arise [144,158]. In some elaborate studies of human monoclonal anti-RBD antibody, specific mutations did not affect neutralization efficacy [159]. Yet more contemporary studies suggest that mutations for $\mathrm{S}$ protein, including the $\mathrm{RBD}$, can be constructed in vitro which do indeed have the potential to escape antibody recognition and neutralization $[160,161]$. A choice of more conserved targets or products with more than one target have the opportunity to overcome any such future dilemma $[162,163]$.

The goals of an effective passive immunotherapy would preferentially include activity to key exposed and targeted viral antigens, sufficient antibody, ease of administration, persistence, resilience to escape mutation, and capability to enact effector functions.

\subsection{Antibody-dependent Enhancement}

For convalescent plasma, IV immunoglobulins (IVIG), or purified antibody (monoclonal or not), there remains the possibility that other beneficial or harmful effects could follow administration that are outside the role of protective immunoglobulin. The use of blood products to modulate immunity specifically in the setting of immunological storm attracts interest [164]. Likewise, there is a time-honored use of plasma for effecting compensatory physiological changes such as for severe hypoalbuminemia and fluid third-spacing dynamics.

In theory, antibody-dependent enhancement (ADE) reflects the potential of virus-specific antibody to promote the disease or create other complications [7,165]. Vaccination with various viruses in animal models best illustrates this phenomenon. Yang and colleagues raised concern about viral entry enhancement in the context of SARS-CoV-1 [166]. To some extent, similar clinical effects may have been seen in past human vaccine trials [7]. Most such effects, whether experimental or clinical, appear to occur after reinfection or vaccination, but have largely either not been seen or looked for in the context of passive immunotherapy [7]. It is also not clear that any such event, categorized in preliminary form as ADE, attracts similar clinical consequences or has the same pathogenesis [167]. From a purely in vitro perspective, there are some methods to gauge the potential for ADE to occur $[159,168]$. While it is yet an issue that attracts attention, the prospect that any such categorized events will prove to complicate SARS-CoV-2 immunotherapy is becoming less likely, as the experience progresses. Such concerns nevertheless may transfer to in vitro re-creation of antibodies (monoclonal or purified plasma) which have modifications of effector function domains. In this context, Zhou et al. [131] have suggested that non-overlapping RBD epitopes may attract differential immune responses which determine whether a humoral immune outcome will foster virus neutralization or ADE.

\subsection{Monoclonal Antibody Derivation and Applications}

If passive immunity confers a beneficial effect, the potential to harness protection through individual antibodies or pools thereof becomes an attractive proposition, especially when a non-human donor source is available at high production capability. As reviewed by Walker and Burton [169], the derivation, modification, and application of monoclonal antibodies are yet in their infancy, despite the vast research that has been conducted thus far. This also applies to their application in the field of coronavirology. Atyeo et al. [170] illustrate how modifications can affect pathological outcomes. Yet, others describe how human monoclonal antibody derivation can vary on the basis of the maturation that occurs in memory B cells [78].

One study found key neutralizing antibodies directed to RBD, N-terminal domain, and quaternary S structures otherwise [171]. Human monoclonal antibodies to RBD have been assessed singly or in tandem $[12,122,159,172]$. Others have examined cocktails of two monoclonal antibodies which recognize non-overlapping epitopes of the S protein [173]. Anti-S human monoclonal antibody produced neutralization in a hamster model [113].

Neutralizing murine monoclonal antibodies have been produced which target RBD [168]. These were thereafter 'humanized' into a chimeric antibody through the combination of the murine $\mathrm{V}$ region to human IgG1/kappa. The revised antibody retained neutralization capacity. In general, the production of humanized antiSARS-CoV-2 monoclonal antibody has promise and has quickly progressed to human trials.

\subsection{Animal Models of Passive Immunity}

Variations of animal models used to assess passive immunity for SARS-CoV-2 infections and their implications for human treatment are detailed in Table 3. Emergent themes include an antiviral effect of convalescent serum which includes both pre-infection protection and amelioration of active disease. Effects are seen to impact on viral replication and pulmonary histopathology. The latter carries through to post-vaccination donor serum or purified IgG. 
Table 3 Key contributions for animal models of passive immunity in SARS-CoV-2 infection

\begin{tabular}{|c|c|c|c|}
\hline References & Model system & Treatment & Outcomes \\
\hline [12] & Murine & $\begin{array}{l}\text { Bioengineered human anti-RBD } 200 \mathrm{mcg} \\
\text { intraperitoneal }\end{array}$ & Both protection and treatment efficacy \\
\hline [38] & Murine & $\begin{array}{l}\text { Human MAb anti-N terminal S protein; } 200 \mathrm{mcg} \\
\text { of single or dual antibodies intraperitoneal }\end{array}$ & Protective effect \\
\hline [112] & Macaque & $\begin{array}{l}\text { Convalescent macaque donor purified IgG; } \\
2.5-250 \mathrm{mg} / \mathrm{kg} \text { for prevention and } 25-250 \mathrm{mg} / \mathrm{kg} \\
\text { for treatment both intravenously }\end{array}$ & $\begin{array}{l}\text { Dose-dependent for prevention, but higher } \\
\text { dose only effective in treatment }\end{array}$ \\
\hline [113] & Hamster & Human MAb 30 mg/kg subcutaneous & $\begin{array}{l}\text { Protective for immunocompetent and } \\
\text { immunosuppressed animals }\end{array}$ \\
\hline [122] & Murine and hamster & $\begin{array}{l}\text { Human MAb anti-RBD intraperitoneal; single } \\
8 \mathrm{mg} / \mathrm{kg} \text { or dual } 1.8-16 \mathrm{mg} / \mathrm{kg}\end{array}$ & $\begin{array}{l}\text { Both protection and treatment efficacy; } \\
\text { Fc functions relevant to outcomes }\end{array}$ \\
\hline [159] & Murine and hamster & Human MAb 2-36 mg/kg intraperitoneal & Both protection and treatment efficacy \\
\hline [168] & Murine & $\begin{array}{l}\text { Two humanized murine MAb } 20 \mathrm{mg} / \mathrm{kg} \\
\text { intraperitoneal four hours post-challenge }\end{array}$ & $\begin{array}{l}\text { Decreased viral load in lung and associated } \\
\text { histopathology }\end{array}$ \\
\hline [170] & Murine and hamster & $\begin{array}{l}\text { Human MAb anti-RBD modulated for Fc } \\
\text { functions; murine } 200 \mathrm{mcg} \text { and hamster } \\
5 \mathrm{mg} / \mathrm{kg} \text { intraperitoneal }\end{array}$ & $\begin{array}{l}\text { Improved treatment outcomes for native } \mathrm{MAb} \\
\text { but enhancement of disease with some } \mathrm{Fc} \\
\text { engineered-variations }\end{array}$ \\
\hline [172] & Murine and rhesus monkey & $\begin{array}{l}\text { Human MAb anti-RBD single or double; murine } \\
200-400 \mathrm{mcg} \text { intraperitoneal and monkey } \\
50 \mathrm{mg} / \mathrm{kg} \text { intravenous }\end{array}$ & $\begin{array}{l}\text { Decreased viral load in lung and associated } \\
\text { histopathology; combination of antibodies } \\
\text { additive }\end{array}$ \\
\hline [173] & Hamster and macaque & $\begin{array}{l}\text { Human MAb REGN-COV2 combination; } \\
\text { hamster } 50 \mathrm{mg} / \mathrm{kg} \text { and macaque } 0.6-150 \mathrm{mg} / \mathrm{kg} \\
\text { intravenous }\end{array}$ & $\begin{array}{l}\text { Both dose-dependent protection and treatment } \\
\text { efficacy }\end{array}$ \\
\hline [174] & Hamster & Hamster convalescent serum $2 \mathrm{~mL}$ intraperitoneal & Inhibited viral replication \\
\hline [175] & Murine & $\begin{array}{l}\text { Post-vaccination donor serum } 600 \mathrm{mcl} \\
\text { intraperitoneal; animals immunized with } \\
\text { S-carrier virus }\end{array}$ & Reduced lung histopathology \\
\hline [176] & Murine & Human convalescent plasma intravenously & $\begin{array}{l}\text { Diminished lung histopathology and prevented } \\
\text { mortality; dose-dependent effect }\end{array}$ \\
\hline [177] & Murine & $\begin{array}{l}\text { Human MAb } 20 \mathrm{mg} / \mathrm{kg} \text { intraperitoneal given } \\
\text { a few hours after challenge }\end{array}$ & $\begin{array}{l}\text { Prevented disease and benefitted active } \\
\text { treatment }\end{array}$ \\
\hline [178] & Murine & Human MAb anti-RBD $1 \mathrm{mg}$ intraperitoneal & $\begin{array}{l}\text { Reduced lung viral load and reduced mortality; } \\
\text { dose-dependent }\end{array}$ \\
\hline [179] & Murine and hamster & $\begin{array}{l}\text { Human MAb anti-RBD } 0.4-10 \mathrm{mg} / \mathrm{kg} \\
\text { intraperitoneal }\end{array}$ & $\begin{array}{l}\text { Both protection and treatment efficacy; murine } \\
\text { dose-dependent; Fc modulation affects } \\
\text { treatment use but not protective capacity }\end{array}$ \\
\hline [180] & Hamster & Human MAb 8 mcg-2 mg intraperitoneal & $\begin{array}{l}\text { Prevented disease; prevention correlated with } \\
\text { circulating antibody levels }\end{array}$ \\
\hline [181] & Rhesus monkey & $\begin{array}{l}\text { Single human MAb anti-RBD given intravenously; } \\
20 \mathrm{mg} / \mathrm{kg} \text { once for prevention and } 50 \mathrm{mg} / \mathrm{kg} \text { twice } \\
\text { for treatment }\end{array}$ & Both protection and treatment efficacy \\
\hline [182] & Murine & $\begin{array}{l}\text { 'Bi-specific' engineered non-overlapping anti-RBD; } \\
\text { antibody derived from two human MAb; } 150 \mathrm{mcg} \\
\text { given intraperitoneally pre-challenge }\end{array}$ & Prevented disease \\
\hline [183] & Murine, hamster, and macaque & $\begin{array}{l}\text { Human MAb anti-RBD; } 10 \mathrm{mg} / \mathrm{kg} \text { intraperitoneal } \\
\text { for rodents and } 10 \mathrm{mg} / \mathrm{kg} \text { for macaques }\end{array}$ & $\begin{array}{l}\text { Preventative and therapeutic for mice; reduced } \\
\text { viral load in hamsters; reduced viral load and } \\
\text { lung pathology in macaques }\end{array}$ \\
\hline
\end{tabular}

MAb, monoclonal antibody; RBD, receptor binding domain of Spike protein; S, Spike.

Efficacy has been largely dose-dependent. These studies supported the ability of humoral immunity transfer to be of clinical value outside of the role of innate or cellular immunity, and give way to credibility for monoclonal antibodies to work singly or in combination.

Considerable work has been done with monoclonal antibodies, especially human-derived. Again, there are variable benefits both for prophylaxis and active treatment in a dose-dependent manner. Reductions are seen in both viral load and lung disease. A multiplicity of monoclonal antibodies can perform better than a single one. Such a strategic tactic was able to protect while giving promise to avoid escape mutations. Most such antibodies are targeted to the
$\mathrm{N}$-terminal of the S protein or the RBD. Effector functions of the antibody Fc fragments can either improve or complicate infection and, thus, considerations on best contour of that region of the antibody are important. There is potential for such immunity to augment protection for immunocompromised patients.

\subsection{Human Trials of Passive Immunity}

Human monoclonal antibody LY-CoV555 (bamlanivimab) was trialed among outpatients with mild to moderate infections, and the investigators reported an interim analysis [184]. Patients were randomized to one of three $(700,2800$ or $7000 \mathrm{mg})$ single intravenous 
doses. The primary endpoint of viral load was the lowest for the 2800-mg dose at day 11, but overall the differences were not dramatic. There was a trend for lower severity of illness among recipients compared to placebo, and there were trends for lower hospital need and visits to an emergency room. Further studies have used similar doses for randomized placebo-controlled trials among mild to moderate infections with LY-CoV555 and LY-CoV016 (etesevimab) [185]. A reduction in viral load was seen, but the effects for secondary outcome measures were variable.

Pre-pandemic IVIG batches from both Europe and the USA did not find significant neutralization titres to SARS-CoV-2, despite the presence of considerable neutralization activity for endemic respiratory coronavirus 229E [186]. In contrast, other IVIG sources from donations collected elsewhere yielded lots which variably neutralized SARS-CoV-1 and SARS-CoV-2, but not MERS-CoV [187]. The latter investigators also found other sources with antibody cross-reactivity to all three of the latter coronaviruses [188]. As the pandemic progresses, there has been considerable improvement in the degree of anti-SARS-CoV-2 seropositivity in IVIG lots, presumably reflecting the seroprevalence that accumulates [189]. Huang et al. [190] retrospectively reviewed cohorts with and without IVIG administration and did not find a beneficial effect. The latter study did not adjust for increased age or increased morbidities found in the treatment group and the dosing was variable (10-20 g/day for 3-5 days). The source of IVIG was not detailed (i.e., pre- or post-pandemic), and no data were provided on the presence of neutralizing or other anti-SARS-CoV-2 antibody. The benefits of IVIG are debatable, but several studies have not determined the pre-existing antiviral potency of the same [191-195]. Such studies do not preclude the potential benefit of IVIG in other niche situations, such as immune thrombocytopenia, ascending polyneuropathy, or multisystem inflammatory disorder attributable to COVID-19 [196-198]. On this theme, however, there is yet potential for the creation of IVIG specifically from donors with convalescent COVID-19 infection. Such 'super' infusions have the theoretical appeal to concentrate what might be beneficial from convalescent plasma otherwise. This concept also allows donor sera of lower neutralization capability to be concentrated, thus allowing for expansion of a donor pool. Concentration of convalescent sera in this fashion may require a considerable number of donor samples.

The development of convalescent donor plasma programs for COVID-19 occurred in short order [199-201]. A proportion of proven-infected donors may not have measurable antibody, and some asymptomatic infections may yet be associated with significant seropositivity $[200,201]$. EIA or neutralizing antibody standards were provisionally set for donor units [103]. The use of donor plasma can soon outstrip the availability in highly endemic scenarios [202]. At screening, however, there is a considerable range of antibody levels [79,80,200,203-205]. There may be some nonserological reasons why prospective donors may be rejected [201]. The collection of convalescent plasma from donor systems should exclude infectiousness, given the detection by some of viral RNA in blood. Andersson et al. [206] found viral RNA in $12.7 \%$ of donor blood product, but could not find infectious virus in a small sample of the latter. Others have not found viral RNA in the donor some weeks to months among post-infection donors [207]. ABO compatibility would be prudent [208,209]. In addition, donor samples with high neutralizing capacity would seem to be the best prospects, but not all single measures of antibody will capture seroconverters [204]. In post-infectious donors, neutralizing antibody $\geq 1 / 160$ was found in approximately $64 \%$ at 28 days after clinical recovery and in approximately $41 \%$ when deemed negative for virus by RNA amplification [105]. Another study found $42 \%$ of samples had neutralization titres $>1: 100$ [133]. After defining a potential donor however, there is a relatively small window in time for continued collection of similar-titred neutralizing samples. It can generally be inferred that high-titred neutralizing donations are better than others. Bradfute et al. [126] found that different measures of recipient antivirus antibody did not change pre- and post-infusion, but relatively low-titred initially unscreened plasma lots had been used. Others have reported no major change in pre- and post-infusion antibody levels in patients despite the use of presumed high EIAtitred donations [127]. Xia et al. [210] found a correlation between plasma donor antivirus antibody quantitation and such antibody in recipient blood. Donor plasma led to increased anti-S1 and anti$\mathrm{RBD}$ antibody but not anti-N antibody levels in recipients. Libster et al. [211] found increased serum antiviral IgG $24 \mathrm{~h}$ after infusion, but the prevailing antibody at that time did not correlate with protection. Donor sera immunoglobulin possess non-neutralization effector functions which may be of variable intensity [34]. It is also relevant to consider that donor plasma may also have other non-immune effects of a salutary nature [166].

The use of convalescent plasma has been anecdotally documented in small patient series as referenced in representative samples [212-238]. These are very difficult to gauge for therapeutic efficacy, given the patient and product variability, concomitant variation in support and other treatment strategies, and the lack of controls [239]. Despite the latter, these studies nevertheless gave some promise that obvious adverse reactions were not common and, hence, provided at least some fodder for test of concept [79]. Such studies were cautiously required especially in the context of severe disease where immunological aberrations of the infection were forefront in concerns. Subsequently, very large reviews of immediate post-infusion safety have been tabulated, and there is a low incidence of acute morbidity directly related to the transfusion product [208,239-241]. Generally, the frequency is <4\% [241]. Some have proposed that infusions might be associated with a reduction in excreted viral load [242]. The latter is contrasted with the lack of association found in one study between persistence of virus RNA detection in respiratory samples and presence of circulating anti-S antibody [84].

Studies with modest to high numbers of patients have now been published for various trials of convalescent plasma prevention and treatment (Table 4). Some generalizations can be extracted, but consistent protocols, doses, and measures among studies are lacking. Given the latter, it would be considerably precarious to assess the data through meta-analyses, although there is often the temptation to do so. In a simulation analysis from sub-Saharan Africa, it was suggested that convalescent plasma therapy was associated with a $50 \%$ mortality reduction [272]. The pointed example detailed by Kemp et al. [157], albeit in a unique patient context, illustrates the potential for SARS-CoV-2 to adapt to selective antibody pressures from donor plasma influence.

The concept of therapeutic plasma exchange followed by convalescent plasma therapy has been discussed [273]. However, it is unclear how removal of potentially pre-existing antibody may 


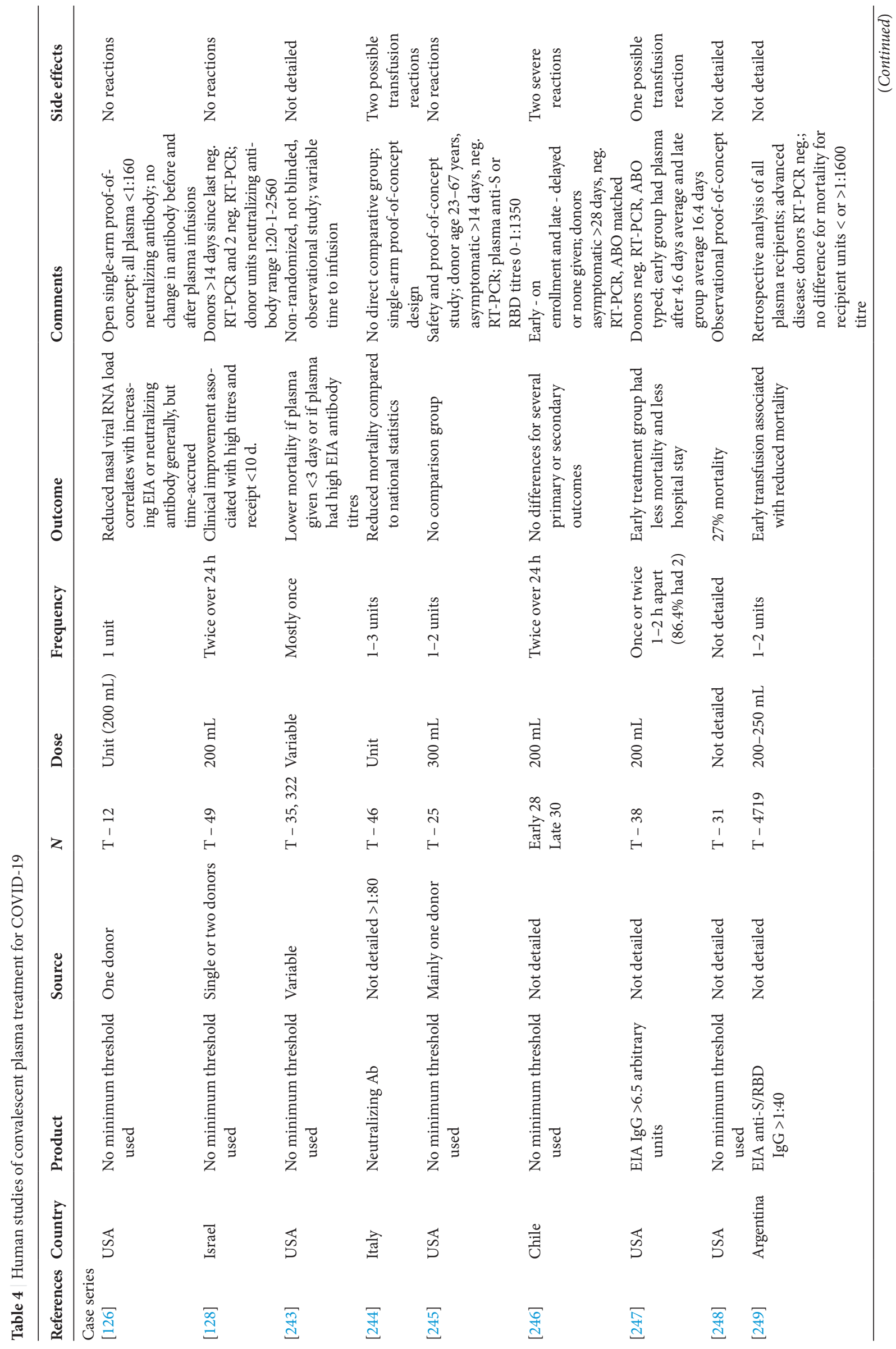




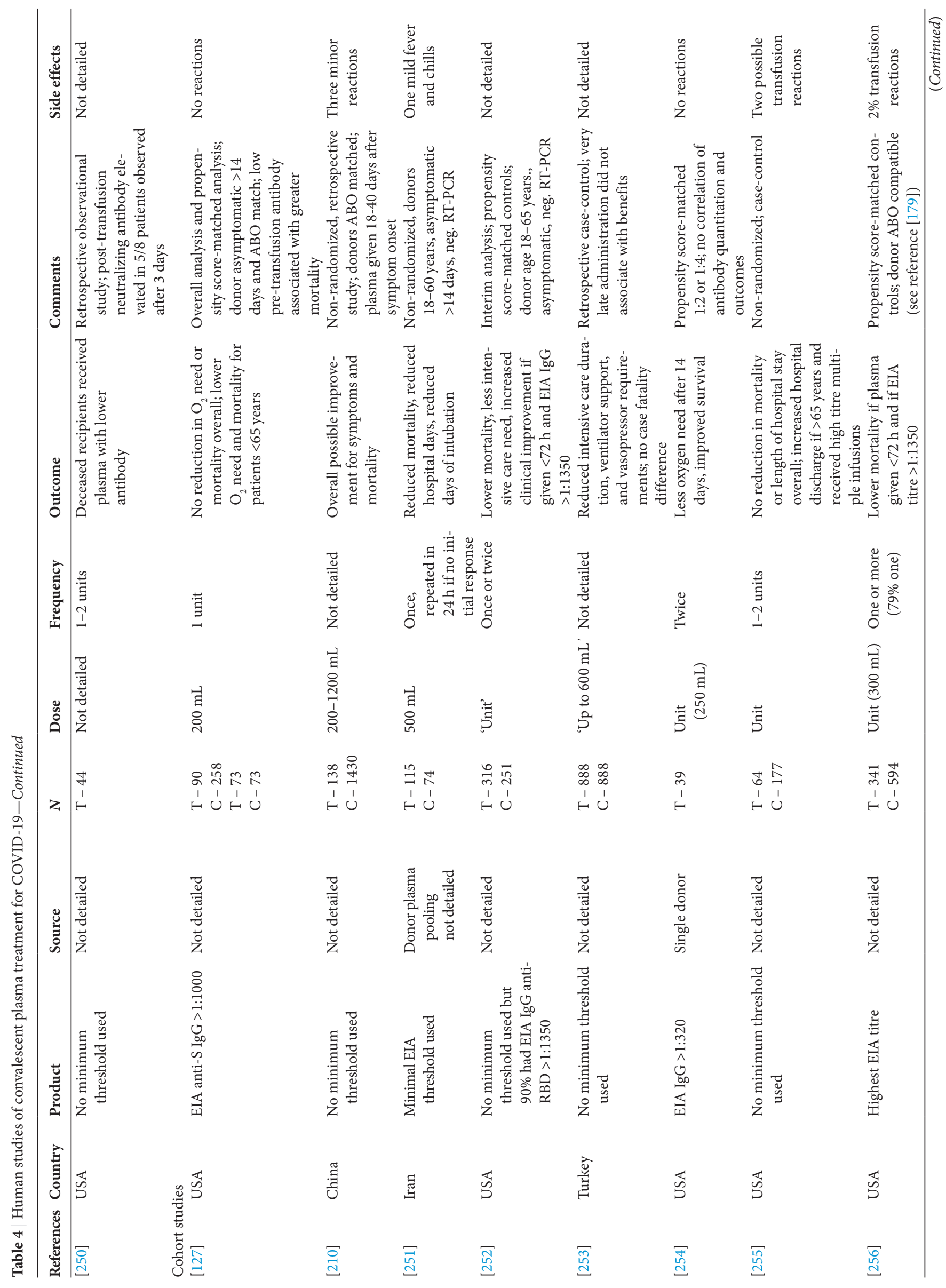




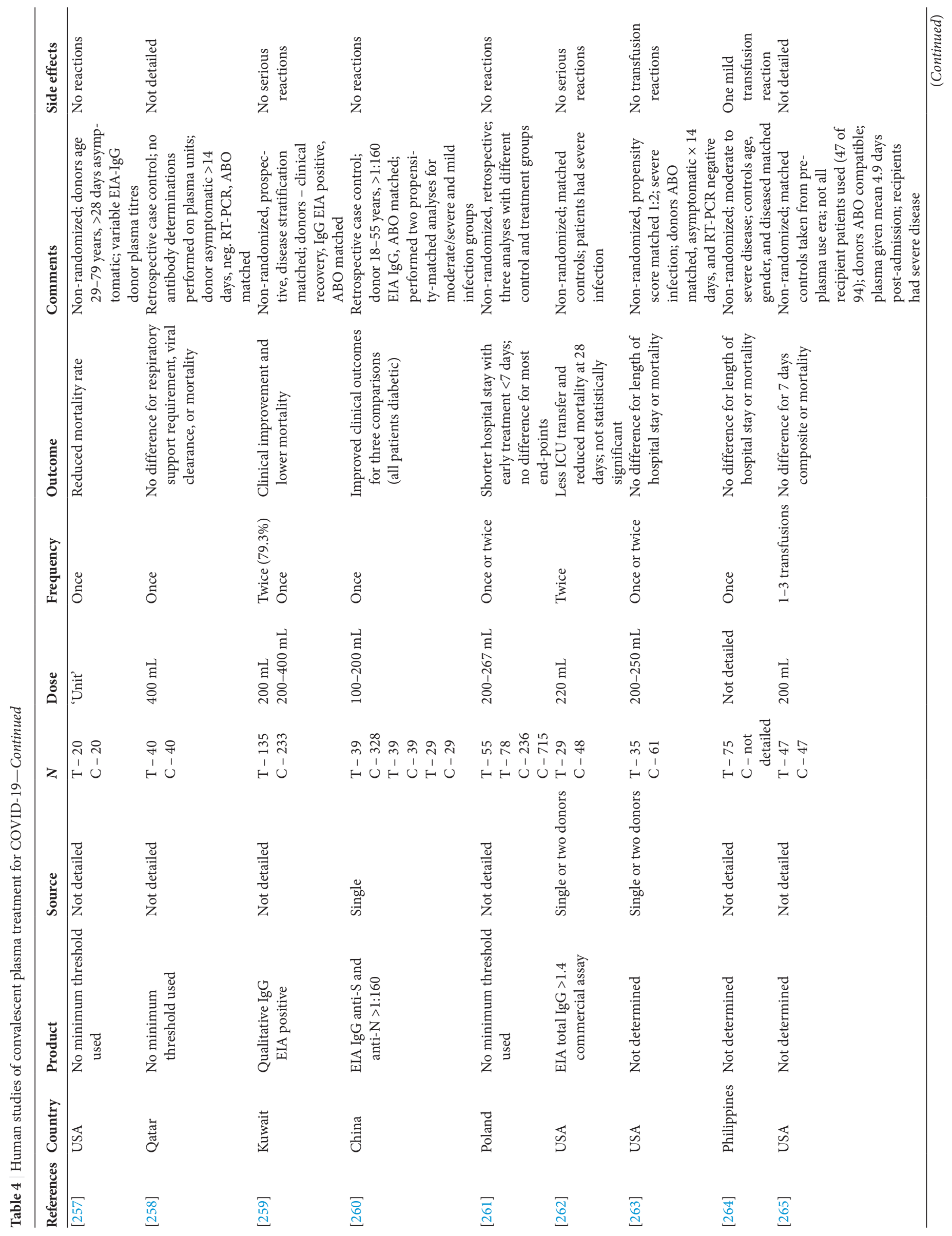




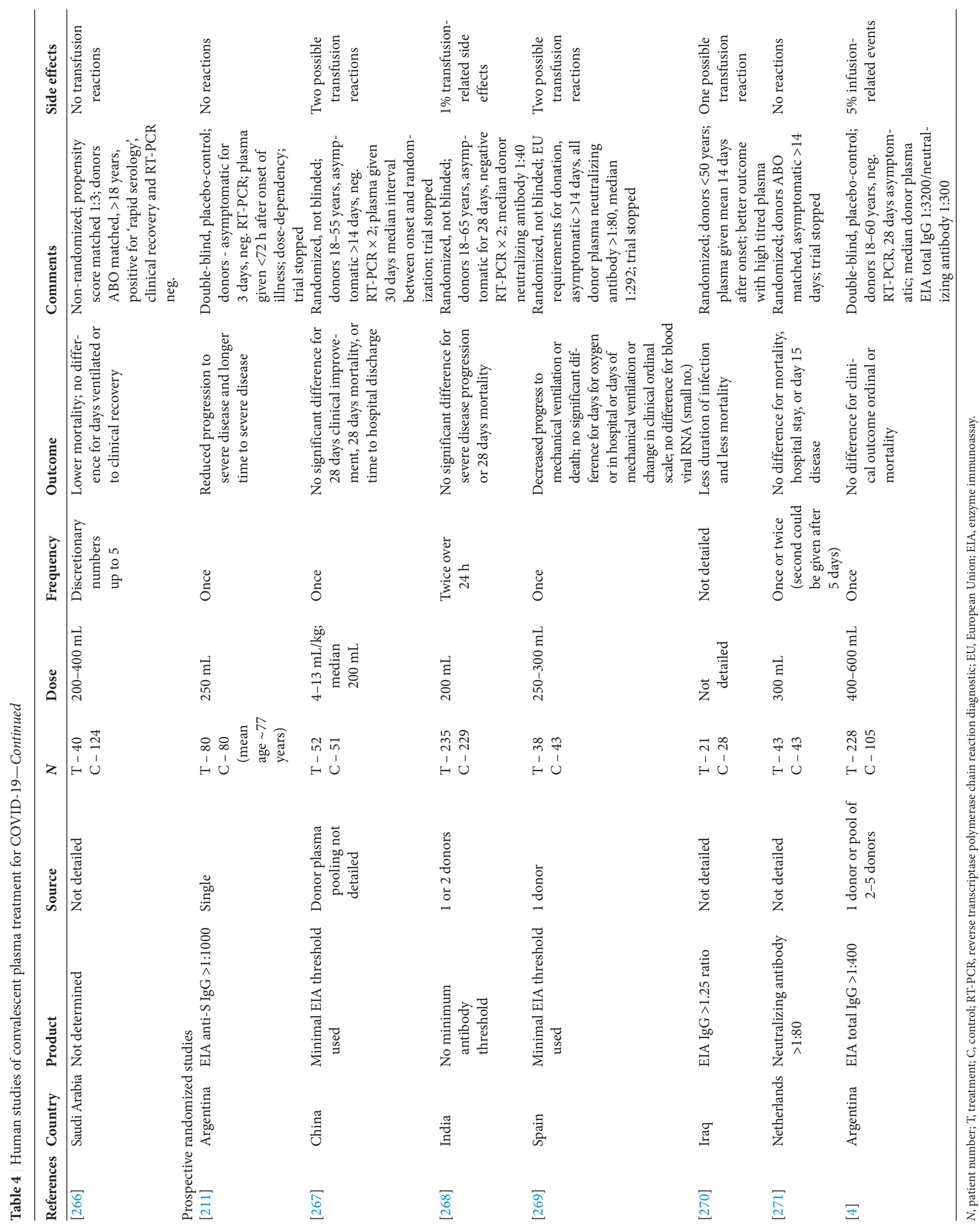


juxtapose with subsequent donor immunity and final outcomes. Another unique but related approach has been piloted by Selzman et al. [274] with the use of therapeutic donor human amniotic fluid. Given intravenously, there is the potential for immunomodulating effects on active COVID-19, but when donated by a convalescent mother who suffered active infection prior to birth, there is also the potential for transfer of maternal virus-directed IgG for a form of passive therapy.

Overall, the findings thus far suggest a dose-dependency and a correlation with better outcome for higher doses of administered donor plasma. The latter approach must also weigh the complicating factors of volume expansion in the short term, if higher doses are met with the need for larger transfusions. A time-dependency with regards to stage of illness also emerges. Repeat donations will need further evaluation. The definition of protective correlates continues to be a high priority.

\section{CURRENT PROSPECTS}

In 2020, emergency use authorizations for convalescent plasma in COVID-19 treatment were being adopted throughout the world. The latter was occurring in a context of relatively limited knowledge but also within a void of effective therapeutic prevention and treatment strategies. In the passion to create immediate and effective products, several aspects of passive immunotherapy have taken somewhat lesser priority.

The pharmacokinetics and immunokinetics of any passive antibody administration are considerably variable among patients. Whether given intravenously or subcutaneously, the volume of distribution is relatively small as a first central compartment. While the antibody may remain in circulation for a variable period of time, entrance into tissue, especially interstitial spaces, follows soon after. Much of this secondary compartmentalization will include sites where viral replication does not necessarily occur. Many of these sites will attract more antibody only due to the inflammatory nature of plasma egress. Given the large molecules of immunoglobulins, degradation immediately through liver or urinary loss are unlikely. Rather, degradation is more likely to occur with proteolytic pathways in sites of active inflammation or through usual protein handling routes. If given by subcutaneous routes, antibody is primed to migrate through lymphatic systems first, rather than direct blood circulatory paths. The handling of such protective antibody through intraperitoneal routes in animal models does not guarantee comparability for human intravenous administration. For monoclonal antibodies, the distribution will be product-specific but susceptible to several patient factors [275]. Apart from non-specific losses, antibody linking to targeted antigens and antigen-processing cells would be desired, but a localized or generalized inflammatory reaction may have various other mechanisms to attract antibody. In addition, some immediate loss may be due to the inadvertent immunogenicity of the product itself, perhaps more significant in multiple infusions. In advanced illnesses, antibody clearance may be enhanced in inverse relationship to the serum albumin concentration which may be low due to the existing biological adversity [276]. The pharmacokinetics of intravenous immunoglobulin are mainly understood from distribution to healthy patients [277,278]. It is not known how the acute inflammation during COVID-19 may alter the latter. When plasma is administered, there will be temporary expansion of the intravascular volume from redirection of body fluid, but the distribution of colloid including antibody is expected to depend on the physiological state as well [279]. For example, clinical sepsis alone can abundantly facilitate capillary leak [280]. The focus of passive immunotherapy has largely been on potency, but the factors of distribution and bioavailability for immunity drivers may be just as, if not more, important.

There is some merit to reconsidering what should have greater priority given the immediate needs of the populace. Monoclonal antibodies may be in favour for many reasons but, practically speaking, a polyclonal multiantigen immunotherapy approach makes most sense, given the potential ability to focus on multiple targets while the virus may slowly change. Multiantigen immunotherapy may also be seen as one that may target multiple exposed and newly formed viral immunogens during the breadth of the infectious process. The concept of IVIG with concentrated polyclonal antivirus activity would allow for a broader collection of donor samples even when they are of lesser whole sample quality. The latter is only a few steps away from the capability of large scale productions. Unfortunately, the latter also introduces the precarious potential for complications of pooled human transfusion. For simple donor plasma infusions, a repeat especially with different donors allows for diversity in the antiviral properties but again creates the potential for enhancing donor-related problems. If virus escape continues to be an issue, as anticipated from the analogy with the yearly behavior of endemic respiratory coronaviruses, the polyclonal approach with donor samples or monoclonal cocktails will take precedence. A polyclonal approach also has the potential to better address the multifunctional Fc effector attributes that may also contribute to the overall beneficial outcomes.

The cumulative laboratory studies suggest that prevention is possible as is active treatment. Passive immunotherapy has focused on the systemic domain but less on mucosal protection. Yet, it is abundantly clear that, in the least, earlier prevention benefits from mucosal antibody [6,7]. Maternal antibody through lactation has one of the greatest potentials for passive protection. Translating other human passive immunity into the sphere of mucosal protection is likely to be highly relevant in the understanding of the larger picture.

Proof-of-concept and open-label studies are necessary parts of progressive scientific endeavor. There is emphasis nonetheless for high quality studies which are placebo-controlled, blinded, and randomized [199,281]. Such studies are relatively complex and require considerable time and effort. While most desirable, they do not preclude lesser attempts which provide cumulative experience. The complexity of passive immunotherapy for the prevention and treatment of COVID-19 is much more than meets the eye. The need for practical and timely interventions necessarily tends to shortcut this complexity, but any failure in outcomes must not dissuade the medical and scientific community from continuing to pursue the next level of design and experimentation, because there will always be a better way. For example, the conjoined effects of immunotherapy and antiviral agents have considerable potential [282]. Passive immunotherapy should and will succeed for some patients. Rational approaches will emerge, as long as the clinical need for these products continues. 


\section{CONFLICTS OF INTEREST}

The author declares no conflicts of interest.

\section{FUNDING}

Funding was not sought for this publication. There is no third party support including that from the pharmaceutical industry.

\section{REFERENCES}

[1] Luke TC, Casadevall A, Watowich SJ, Hoffman SL, Beigel JH, Burgess TH. Hark back: passive immunotherapy for influenza and other serious infections. Crit Care Med 2010;38;e66-e73.

[2] Cimolai N. Pharmacotherapy for Bordetella pertussis infection. II. A synthesis of clinical sciences. Int J Antimicrob Agents $2021 ; 57 ; 106257$

[3] Mair-Jenkins J, Saavedra-Campos M, Baillie JK, Cleary P, Khaw FM, Lim WS, et al. The effectiveness of convalescent plasma and hyperimmune immunoglobulin for the treatment of severe acute respiratory infections of viral etiology: a systematic review and exploratory meta-analysis. J Infect Dis 2015;211;80-90.

[4] Simonovich VA, Burgos Pratx LD, Scibona P, Beruto MV, Vallone MG, Vázquez C, et al. A randomized trial of convalescent plasma in Covid-19 severe pneumonia. N Engl J Med 2021;384;619-29.

[5] Cimolai N. Complicating infections associated with common endemic human respiratory coronaviruses. Health Secur 2021; 19;195-208.

[6] Cimolai N. A minimalist strategy towards temporarily defining protection for COVID-19. SN Compr Clin Med 2020;2;2059-66.

[7] Cimolai N. Applying immune instincts and maternal intelligence from comparative microbiology to COVID-19. SN Compr Clin Med 2020;2;2670-83.

[8] Callow KA. Effect of specific humoral immunity and some non-specific factors on resistance of volunteers to respiratory coronavirus infection. J Hyg (Lond) 1985;95;173-89.

[9] Callow KA, Parry HF, Sergeant M, Tyrrell DAJ. The time course of the immune response to experimental coronavirus infection of man. Epidemiol Infect 1990;105;435-46.

[10] Subbarao K, McAuliffe J, Vogel L, Fahle G, Fischer S, Tatti K, et al. Prior infection and passive transfer of neutralizing antibody prevent replication of severe acute respiratory syndrome coronavirus in the respiratory tract of mice. J Virol 2004;78;3572-7.

[11] Roberts A, Thomas WD, Guarner J, Lamirande EW, Babcock GJ, Greenough TC, et al. Therapy with a severe acute respiratory syndrome-associated coronavirus-neutralizing human monoclonal antibody reduces disease severity and viral burden in golden Syrian hamsters. J Infect Dis 2006;193;685-92.

[12] Rappazzo CG, Tse LV, Kaku CI, Wrapp D, Sakharkar M, Huang $\mathrm{D}$, et al. An engineered antibody with broad protective efficacy in murine models of SARS and COVID-19. bioRxiv 2020;2020.11.17.385500 [Preprint].

[13] Soo YOY, Cheng Y, Wong R, Hui DS, Lee CK, Tsang KKS, et al. Retrospective comparison of convalescent plasma with continuing high-dose methylprednisolone treatment in SARS patients. Clin Microbiol Infect 2004;10;676-8.

[14] Cheng Y, Wong R, Soo YOY, Wong WS, Lee CK, Ng MHL, et al. Use of convalescent plasma therapy in SARS patients in Hong Kong. Eur J Clin Microbiol Infect Dis 2005;24;44-6.
[15] Li Y, Wan Y, Liu P, Zhao J, Lu G, Qi J, et al. A humanized neutralizing antibody against MERS-CoV targeting the receptor-binding domain of the spike protein. Cell Res 2015;25;1237-49.

[16] Qiu H, Sun S, Xiao H, Feng J, Guo Y, Tai W, et al. Single-dose treatment with a humanized neutralizing antibody affords full protection of a human transgenic mouse model from lethal Middle East Respiratory Syndrome (MERS)-coronavirus infection. Antiviral Res 2016;132;141-8.

[17] Sivapalasingam S, Saviolakis GA, Kulcsar K, Nakamura A, Conrad T, Hassanein M, et al. Human monoclonal antibody cocktail for the treatment or prophylaxis of Middle East Respiratory Syndrome coronavirus. J Infect Dis 2021;jiab036 [Epub ahead of print].

[18] Abbas AT, El-Kafrawy SA, Sohrab SS, Tabll AA, Hassan AM, Iwata-Yoshikawa N, et al. Anti-S1 MERS-COV IgY specific antibodies decreases lung inflammation and viral antigen positive cells in the human transgenic mouse model. Vaccines (Basel) $2020 ; 8 ; 634$.

[19] Zhao Y, Wang C, Qiu B, Li C, Wang H, Jin H, et al. Passive immunotherapy for Middle East Respiratory Syndrome coronavirus infection with equine immunoglobulin or immunoglobulin fragments in a mouse model. Antiviral Res 2017;137;125-30.

[20] Kim YS, Aigerim A, Park U, Kim Y, Park H, Rhee JY, et al. Sustained responses of neutralizing antibodies against MERS$\mathrm{CoV}$ in recovered patients and their therapeutic applicability. Clin Infect Dis 2020; ciaa1345 [Epub ahead of print].

[21] de Wit E, Feldmann F, Okumura A, Horne E, Haddock E, Saturday G, et al. Prophylactic and therapeutic efficacy of $\mathrm{mAb}$ treatment against MERS-CoV in common marmosets. Antiviral Res 2018;156;64-71.

[22] van Doremalen N, Falzarano D, Ying T, de Wit E, Bushmaker T, Feldmann F, et al. Efficacy of antibody-based therapies against Middle East respiratory syndrome coronavirus (MERS-CoV) in common marmosets. Antiviral Res 2017;143;30-7.

[23] Bonifacius A, Tischer-Zimmermann S, Dragon AC, Gussarow D, Vogel A, Krettek U, et al. COVID-19 immune signatures reveal stable antiviral $\mathrm{T}$ cell function despite declining humoral responses. Immunity 2021;54;340.e6-54.e6.

[24] Laing ED, Sterling SL, Richard SA, Epsi NJ, Coggins S, Samuels EC, et al. Antigen-based multiplex strategies to discriminate SARS-CoV-2 natural and vaccine induced immunity from seasonal human coronavirus humoral responses. medRxiv 2021; 2021.02.10.21251518 [Preprint].

[25] Becker M, Strengert M, Junker D, Kaiser PD, Kerrinnes T, Traenkle B, et al. Exploring beyond clinical routine SARS-CoV-2 serology using MultiCoV-Ab to evaluate endemic coronavirus cross-reactivity. Nat Commun 2021;12;1152.

[26] Anderson EM, Goodwin EC, Verma A, Arevalo CP, Bolton MJ, Weirick ME, et al. Seasonal human coronavirus antibodies are boosted upon SARS-CoV-2 infection but not associated with protection. Cell 2021;184;1858.e10-64.e10.

[27] Morgenlander WR, Henson SN, Monaco DR, Chen A, Littlefield $\mathrm{K}$, Bloch EM, et al. Antibody responses to endemic coronaviruses modulate COVID-19 convalescent plasma functionality. J Clin Invest 2021;131;e146927.

[28] Sakharkar M, Rappazzo CG, Wieland-Alter WF, Hsieh CL, Wrapp D, Esterman ES, et al. Prolonged evolution of the human B cell response to SARS-CoV-2 infection. Sci Immunol 2021; 6; eabg6916.

[29] Dugas M, Grote-Westrick T, Vollenberg R, Lorentzen E, Brix T, Schmidt H, et al. Less severe course of COVID-19 is associated with elevated levels of antibodies against seasonal human 
coronaviruses OC43 and HKU1 (HCoV OC43, HCov HKU1). Int J Infect Dis 2021;105;304-6.

[30] Dispinseri S, Secchi M, Pirillo MF, Tolazzi M, Borghi M, Brigatti C, et al. COVID-BioB Cohort Study: the neutralizing antibody response to SARS-CoV-2 in symptomatic COVID-19 is persistent and critical for virus control and survival. medRxiv 2021 [Epub ahead of print].

[31] Cohen CA, Li AP, Hachim A, Hui DS, Kwan MY, Tsang OT, et al. SARS-CoV-2 specific T cell responses are lower in children and increase with age and time after infection. medRxiv 2021;2021.02.02.21250988 [Preprint].

[32] Mariano G, Farthing RJ, Lale-Farjat SLM, Bergeron JRC. Structural characterization of SARS-CoV-2: where we are, and where we need to be. Front Mol Biosci 2020;7;605236.

[33] Salazar E, Kuchipudi SV, Christensen PA, Eagar TN, Yi X, Zhao P, et al. Relationship between anti-Spike protein antibody titers and SARS-CoV-2 in vitro virus neutralization in convalescent plasma. bioRxiv 2020;2020.06.08.138990 [Preprint].

[34] Natarajan H, Crowley AR, Butler SE, Xu S, Weiner JA, Bloch EM, et al. SARS-CoV-2 antibody signatures robustly predict diverse antiviral functions relevant for convalescent plasma therapy. medRxiv 2020;2020.09.16.20196154 [Preprint].

[35] Klein SL, Pekosz A, Park HS, Ursin RL, Shapiro JR, Benner SE, et al. Sex, age, and hospitalization drive antibody responses in a COVID-19 convalescent plasma donor population. J Clin Invest 2020;130;6141-50.

[36] Li K, Huang B, Wu M, Zhong A, Li L, Cai Y, et al. Dynamic changes in anti-SARS-CoV-2 antibodies during SARS-CoV-2 infection and recovery from COVID-19. Nat Commun 2020;11;6044.

[37] Secchi M, Bazzigaluppi E, Brigatti C, Marzinotto I, Tresoldi C, Rovere-Querini P, et al. COVID-19 survival associates with the immunoglobulin response to the SARS-CoV-2 spike receptor binding domain. J Clin Invest 2020;130;6366-78.

[38] Voss WN, Hou YJ, Johnson NV, Kim JE, Delidakis G, Horton AP, et al. Prevalent, protective, and convergent IgG recognition of SARS-CoV-2 non-RBD spike epitopes in COVID-19 convalescent plasma. bioRxiv 2020;2020.12.20.423708 [Preprint].

[39] Guthmiller JJ, Stovicek O, Wang J, Changrob S, Li L, Halfmann P, et al. SARS-CoV-2 infection severity is linked to superior humoral immunity against the spike. mBio 2021; 12; $02940-20$.

[40] Heffron AS, McIlwain SJ, Baker DA, Amjadi MF, Khullar S, Sethi AK, et al. The landscape of antibody binding to SARS-CoV-2. bioRxiv 2020;2020.10.10.334292 [Preprint].

[41] Martínez-Fleta P, Alfranca A, González-Álvaro I, Casasnovas JM, Fernández-Soto D, Esteso G, et al. SARS-CoV-2 cysteine-like protease antibodies can be detected in serum and saliva of COVID-19-seropositive individuals. J Immunol 2020;205;3130-40.

[42] de Assis RR, Jain A, Nakajima R, Jasinskas A, Felgner J, Obiero JM, et al. Analysis of SARS-CoV-2 antibodies in COVID-19 convalescent blood using a coronavirus antigen microarray. Nat Commun 2021;12;6.

[43] Freedenberg AT, Pan CH, Diehl WE, Romeiser JL, Hwang GR, Leiton CV, et al. Neutralizing activity to SARS-CoV-2 of convalescent and control plasma used in a randomized controlled trial. Transfusion 2021 [Epub ahead of print].

[44] Smits VAJ, Hernández-Carralero E, Paz-Cabrera MC, Cabrera E, Hernández-Reyes Y, Hernández-Fernaud JR, et al. The nucleocapsid protein triggers the main humoral immune response in COVID-19 patients. Biochem Biophys Res Commun 2021;543;45-9.
[45] Ng KW, Faulkner N, Cornish GH, Rosa A, Harvey R, Hussain S, et al. Preexisting and de novo humoral immunity to SARS-CoV-2 in humans. Science 2020;370;1339-43.

[46] Martin S, Heslan C, Jégou G, Eriksson LA, Le Gallo M, Thibault $\mathrm{V}$, et al. SARS-CoV2 envelop proteins reshape the serological responses of COVID-19 patients. bioRxiv 2021 [Preprint].

[47] Nielsen SCA, Yang F, Jackson KJL, Hoh RA, Röltgen K, Jean GH, et al. Human B cell clonal expansion and convergent antibody responses to SARS-CoV-2. Cell Host Microbe 2020;28;516-525.e5.

[48] Juno JA, Tan HX, Lee WS, Reynaldi A, Kelly HG, Wragg K, et al. Humoral and circulating follicular helper $\mathrm{T}$ cell responses in recovered patients with COVID-19. Nat Med 2020;26; $1428-34$

[49] Robbiani DF, Gaebler C, Muecksch F, Lorenzi JCC, Wang Z, Cho A, et al. Convergent antibody responses to SARS-CoV-2 in convalescent individuals. Nature 2020;584;437-42.

[50] Piccoli L, Park YJ, Tortorici MA, Czudnochowski N, Walls AC, Beltramello $\mathrm{M}$, et al. Mapping neutralizing and immunodominant sites on theSARS-CoV-2 spike receptor-binding domain bystructureguided high-resolution serology. Cell 2020;183;1024.e21-42.e21.

[51] Dan JM, Mateus J, Kato Y, Hastie KM, Yu ED, Faliti CE, et al. Immunological memory to SARS-CoV-2 assessed for up to 8 months after infection. Science 2021;371; eabf4063.

[52] Li L, Tong X, Chen H, He R, Lv Q, Yang R, et al. Characteristics and serological patterns of COVID-19 convalescent plasma donors: optimal donors and timing of donation. Transfusion 2020;60;1765-72.

[53] Wang K, Long QX, Deng HJ, Hu J, Gao QZ, Zhang GJ, et al. Longitudinal dynamics of the neutralizing antibody response to Severe Acute Respiratory Syndrome Coronavirus 2 (SARS-CoV-2) infection. Clin Infect Dis 2020; ciaa1143 [Epub ahead of print].

[54] Beaudoin-Bussières G, Laumaea A, Anand SP, Prévost J, Gasser R, Goyette G, et al. Decline of humoral responses against SARS-CoV-2 spike in convalescent individuals. mBio 2020;11; e02590-20.

[55] Lee WT, Girardin RC, Dupuis AP, Kulas KE, Payne AF, Wong SJ, et al. Neutralizing antibody responses in COVID-19 convalescent sera. J Infect Dis 2021;223;47-55.

[56] De Donno A, Lobreglio G, Panico A, Grassi T, Bagordo F, Bozzetti MP, et al. IgM and IgG profiles reveal peculiar features of humoral immunity response to SARS-CoV-2 infection. Int J Environ Res Public Health 2021;18;1318.

[57] Sherina N, Piralla A, Du L, Wan H, Kumagai-Braesch M, Andréll J, et al. Persistence of SARS-CoV-2 specific B and T-cell responses in convalescent COVID-19 patients 6-8 months after the infection. Med (N Y) 2021;2;281.e4-95.e4.

[58] Kutsuna S, Asai Y, Matsunaga A, Kinoshita N, Terada M, Miyazato Y, et al. Factors associated with anti-SARS-CoV-2 IgG antibody production in patients convalescing from COVID-19. J Infect Chemother 2021;27;808-13.

[59] Isho B, Abe KT, Zuo M, Jamal AJ, Rathod B, Wang JH, et al. Persistence of serum and saliva antibody responses to SARSCoV-2 spike antigens in COVID-19 patients. Sci Immunol 2020;5; eabe5511.

[60] Lynch KL, Whitman JD, Lacanienta NP, Beckerdite EW, Kastner SA, Shy BR, et al. Magnitude and kinetics of anti-severe acute respiratory syndrome coronavirus 2 antibody responses and their relationship to disease severity. Clin Infect Dis 2021;72;301-8.

[61] Zhang X, Lu S, Li H, Wang Y, Lu Z, Liu Z, et al. Viral and antibody kinetics of COVID-19 patients with different disease severities in 
acute and convalescent phases: a 6-month follow-up study. Virol Sin 2020;35;820-9.

[62] Iyer AS, Jones FK, Nodoushani A, Kelly M, Becker M, Slater D, et al. Dynamics and significance of the antibody response to SARS-CoV-2 infection. medRxiv 2020;2020.07.18.20155374 [Preprint].

[63] Tan Y, Liu F, Xu X, Ling Y, Huang W, Zhu Z, et al. Durability of neutralizing antibodies and T-cell response post SARS-CoV-2 infection. Front Med 2020;14;746-51.

[64] Graham NR, Whitaker AN, Strother CA, Miles AK, Grier D, McElvany BD, et al. Kinetics and isotype assessment of antibodies targeting the spike protein receptor-binding domain of severe acute respiratory syndrome-coronavirus-2 in COVID-19 patients as a function of age, biological sex and disease severity. Clin Transl Immunology 2020;9;e1189.

[65] Rodda LB, Netland J, Shehata L, Pruner KB, Morawski PA, Thouvenel CD, et al. Functional SARS-CoV-2-specific immune memory persists after mild COVID-19. Cell 2021;184;169e17183.e17.

[66] Anand SP, Prévost J, Nayrac M, Beaudoin-Bussières G, Benlarbi M, Gasser R, et al. Longitudinal analysis of humoral immunity against SARS-CoV-2 Spike in convalescent individuals up to 8 months post-symptom onset. bioRxiv 2021;2021.01.25.428097 [Preprint].

[67] Fischer B, Lindenkamp C, Lichtenberg C, Birschmann IE, Knabbe C, Hendig D. Evidence of long-lasting humoral and cellular immunity against SARS-CoV-2 even in elderly COVID-19 convalescents showing a mild to moderate disease progression. medRxiv 2021 [Preprint].

[68] Carsetti R, Zaffina S, Piano Mortari E, Terreri S, Corrente F, Capponi $\mathrm{C}$, et al. Different innate and adaptive immune responses to SARS-CoV-2 infection of asymptomatic, mild, and severe cases. Front Immunol 2020;11;610300.

[69] Wang Z, Lorenzi JCC, Muecksch F, Finkin S, Viant C, Gaebler C, et al. Enhanced SARS-CoV-2 neutralization by dimeric IgA. Sci Transl Med 2021;13; eabf1555.

[70] Ladage D, Harzer O, Engel P, Winkler H, Braun RJ. Persisting adaptive immunity to SARS-CoV-2 in Lower Austria. medRxiv 2021 [Preprint].

[71] Cervia C, Nilsson J, Zurbuchen Y, Valaperti A, Schreiner J, Wolfensberger A, et al. Systemic and mucosal antibody responses specific to SARS-CoV-2 during mild versus severe COVID-19. J Allergy Clin Immunol 2020;147;545.e9-57.e9.

[72] Chen W, Zhang J, Qin X, Wang W, Xu M, Wang LF, et al. SARSCoV-2 neutralizing antibody levels are correlated with severity of COVID-19 pneumonia. Biomed Pharmacother 2020;130; 110629.

[73] Legros V, Denolly S, Vogrig M, Boson B, Siret E, Rigaill J, et al. A longitudinal study of SARS-CoV-2-infected patients reveals a high correlation between neutralizing antibodies and COVID-19 severity. Cell Mol Immunol 2021;18;318-27.

[74] Demaret J, Lefèvre G, Vuotto F, Trauet J, Duhamel A, Labreuche J, et al. Severe SARS-CoV-2 patients develop a higher specific T-cell response. Clin Transl Immunology 2020;9;e1217.

[75] Anichini G, Gandolfo C, Terrosi C, Fabrizi S, Miceli GB, Gori Savellini G, et al. Antibody response to SARS-CoV-2 in infected patients with different clinical outcome. J Med Virol 2021;93;2548-52.

[76] Kowitdamrong E, Puthanakit T, Jantarabenjakul W, Prompetchara E, Suchartlikitwong P, Putcharoen O, et al. Antibody responses to SARS-CoV-2 in patients with differing severities of coronavirus disease 2019. PLoS One 2020;15;e0240502.

[77] Petersen LR, Sami S, Vuong N, Pathela P, Weiss D, Morgenthau $\mathrm{BM}$, et al. Lack of antibodies to Severe Acute Respiratory Syndrome Coronavirus 2 (SARS-CoV-2) in a large cohort of previously infected persons. Clin Infect Dis 2020; ciaa1685.

[78] Gaebler C, Wang Z, Lorenzi JCC, Muecksch F, Finkin S, Tokuyama M, et al. Evolution of antibody immunity to SARSCoV-2. Nature 2021;591;639-44.

[79] Madariaga MLL, Guthmiller JJ, Schrantz S, Jansen MO, Christensen C, Kumar M, et al. Clinical predictors of donor antibody titre and correlation with recipient antibody response in a COVID-19 convalescent plasma clinical trial. J Intern Med 2020;289;559-73.

[80] Jungbauer C, Weseslindtner L, Weidner L, Gänsdorfer S, Farcet MR, Gschalder-Reichhart E, et al. Characterization of 100 sequential SARS-CoV-2 convalescent plasma donations. Transfusion 2021;61;12-16.

[81] Bošnjak B, Stein SC, Willenzon S, Cordes AK, Puppe W, Bernhardt $G$, et al. Low serum neutralizing anti-SARS-CoV-2 S antibody levels in mildly affected COVID-19 convalescent patients revealed by two different detection methods. Cell Mol Immunol 2021;18;936-44.

[82] Mehew J, Johnson R, Roberts D, Harvala H. Convalescent plasma for COVID-19: male gender, older age and hospitalisation associated with high neutralising antibody levels, England, 22 April to 12 May 2020. Euro Surveill 2020;25;2001754.

[83] Terpos E, Politou M, Sergentanis TN, Mentis A, Rosati M, Stellas D, et al. Anti-SARS-CoV-2 antibody responses in convalescent plasma donors are increased in hospitalized patients; subanalyses of a phase 2 clinical study. Microorganisms 2020;8;1885.

[84] Ikegami S, Benirschke R, Flanagan T, Tanna N, Klein T, Elue R, et al. Persistence of SARS-CoV-2 nasopharyngeal swab PCR positivity in COVID-19 convalescent plasma donors. Transfusion 2020;60;2962-8.

[85] Van Elslande J, Oyaert M, Ailliet S, Van Ranst M, Lorent N, Vande Weygaerde Y, et al. Longitudinal follow-up of IgG anti-nucleocapsid antibodies in SARS-CoV-2 infected patients up to eight months after infection. J Clin Virol 2021;136;104765.

[86] Markmann AJ, Giallourou N, Bhowmik DR, Hou YJ, Lerner A, Martinez DR, et al. Sex disparities and neutralizing antibody durability to SARS-CoV-2 infection in convalescent individuals. medRxiv 2021;2021.02.01.21250493 [Preprint].

[87] Bavaro DF, Laghetti P, Milano E, Brindicci G, Volpe A, Lagioia A, et al. Anti-spike S1 receptor-binding domain antibodies against SARS-CoV-2 persist several months after infection regardless of disease severity. J Med Virol 2021;93;3158-64.

[88] Ren L, Zhang L, Chang D, Wang J, Hu Y, Chen H, et al. The kinetics of humoral response and its relationship with the disease severity in COVID-19. Commun Biol 2020;3;780.

[89] Bartsch YC, Wang C, Zohar T, Fischinger S, Atyeo C, Burke JS, et al. Humoral signatures of protective and pathological SARSCoV-2 infection in children. Nat Med 2021;27;454-62.

[90] Yang HS, Racine-Brzostek SE, Karbaschi M, Yee J, Dillard A, Steel PAD, et al. Testing-on-a-probe biosensors reveal association of early SARS-CoV-2 total antibodies and surrogate neutralizing antibodies with mortality in COVID-19 patients. Biosens Bioelectron 2021;178;113008.

[91] Koblischke M, Traugott MT, Medits I, Spitzer FS, Zoufaly A, Weseslindtner L, et al. Dynamics of CD4 T cell and antibody 
responses in COVID-19 patients with different disease severity. Front Med (Lausanne) 2020;7;592629.

[92] Staines HM, Kirwan DE, Clark DJ, Adams ER, Augustin Y, Byrne RL, et al. IgG seroconversion and pathophysiology in severe acute respiratory syndrome coronavirus 2 infection. Emerg Infect Dis 2021;27;85-91.

[93] Nelde A, Bilich T, Heitmann JS, Maringer Y, Salih HR, Roerden $\mathrm{M}$, et al. SARS-CoV-2-derived peptides define heterologous and COVID-19-induced T cell recognition. Nat Immunol 2021; $22 ; 74-85$.

[94] Bacher P, Rosati E, Esser D, Rios Martini G, Saggau C, Schiminsky E, et al. Low-avidity $\mathrm{CD}^{+} \mathrm{T}$ cell responses to SARS-CoV-2 in unexposed individuals and humans with severe COVID-19. Immunity 2020;53;1258.e5-71.e5.

[95] Milani GP, Dioni L, Favero C, Cantone L, Macchi C, Delbue S, et al. Serological follow-up of SARS-CoV-2 asymptomatic subjects. Sci Rep 2020;10;20048.

[96] Sakhi H, Dahmane D, Attias P, Kofman T, Bouvier M, Lapidus $\mathrm{N}$, et al. Kinetics of anti-SARS-CoV-2 IgG antibodies in hemodialysis patients six months after infection. J Am Soc Nephrol 2021;ASN.2020111618 [Epub ahead of print].

[97] Hempel L, Molnar J, Robert S, Veloso J, Trepotec Z, Englisch S, et al. Rare SARS-CoV-2 antibody development in cancer patients. Semin Oncol 2021;S0093-7754(20)30124-X [Epub ahead of print].

[98] Moderbacher CR, Ramirez SI, Dan JM, Grifoni A, Hastie KM, Weiskopf D, et al. Antigen-specific adaptive immunity to SARSCoV-2 in acute COVID-19 and associations with age and disease severity. Cell 2020;183;996.e19-1012.e19.

[99] Zohar T, Loos C, Fischinger S, Atyeo C, Wang C, Slein MD, et al. Compromised humoral functional evolution tracks with SARSCoV-2 mortality. Cell 2020;183;1508.e12-19.e12.

[100] Anand SP, Prévost J, Richard J, Perreault J, Tremblay T, Drouin $\mathrm{M}$, et al. High-throughput detection of antibodies targeting the SARS-CoV-2 Spike in longitudinal convalescent plasma samples. Transfusion 2021 [Epub ahead of print].

[101] Deisenhammer F, Borena W, Bauer A, Kimpel J, Rudzki D, Schanda K, et al. 6-month SARS-CoV-2 antibody persistency in a Tyrolian COVID-19 cohort. Wien Kin Wochenschr 2020;1-8 [Epub ahead of print].

[102] Schwarzkopf S, Krawczyk A, Knop D, Klump H, Heinold A, Heinemann FM, et al. Cellular immunity in COVID-19 convalescents with PCR-confirmed infection but with undetectable SARS-CoV-2-specific IgG. Emerg Infect Dis 2021;27;122-9.

[103] Girardin RC, Dupuis AP, Payne AF, Sullivan TJ, Strauss D, Parker MM, et al. Temporal analysis of serial donations reveals decrease in neutralizing capacity and justifies revised qualifying criteria for coronavirus disease 2019 convalescent plasma. J Infect Dis 2021;223;743-51.

[104] Harvala H, Mehew J, Robb ML, Ijaz S, Dicks S, Patel M, et al. Convalescent plasma treatment for SARS-CoV-2 infection: analysis of the first 436 donors in England, 22 April to 12 May 2020. Euro Surveill 2020;25;2001260.

[105] Wendel S, Kutner JM, Machado R, Fontão-Wendel R, Bub C, Fachini R, et al. Screening for SARS-CoV-2 antibodies in convalescent plasma in Brazil: preliminary lessons from a voluntary convalescent donor program. Transfusion 2020;60;2938-51.

[106] Schlickeiser S, Schwarz T, Steiner S, Wittke K, Al Besher N, Meyer O, et al. Disease severity, fever, age, and sex correlate with
SARS-CoV-2 neutralizing antibody responses. Front Immunol 2021;11;628971.

[107] Nguyen-Contant P, Embong AK, Kanagaiah P, Chaves FA, Yang $\mathrm{H}$, Branche AR, et al. S protein-reactive IgG and memory B cell production after human SARS-CoV-2 infection includes broad reactivity to the S2 subunit. mBio 2020;11;e01991-20.

[108] Lee E, Sandgren K, Duette G, Stylianou VV, Khanna R, Eden JS, et al. Identification of SARS-CoV-2 nucleocapsid and spike T-cell epitopes for assessing T-cell immunity. J Virol 2020;95;e02002-20.

[109] Keller MD, Harris KM, Jensen-Wachspress MA, Kankate VV, Lang H, Lazarski CA, et al. SARS-CoV-2-specific T cells are rapidly expanded for therapeutic use and target conserved regions of the membrane protein. Blood 2020;136;2905-17.

[110] Orologas-Stavrou N, Politou M, Rousakis P, Kostopoulos IV, Ntanasis-Stathopoulos I, Jahaj E, et al. Peripheral blood immune profiling of convalescent plasma donors reveals alterations in specific immune subpopulations even at 2 months post SARSCoV-2 infection. Viruses 2020;13;26.

[111] Peluso MJ, Deitchman AN, Torres L, Iyer NS, Nixon CC, Munter SE, et al. Long-term SARS-CoV-2-specific immune and inflammatory responses across a clinically diverse cohort of individuals recovering from COVID-19. medRxiv 2021; 2021.02.26.21252308

[112] McMahan K, Yu J, Mercado NB, Loos C, Tostanoski LH, Chandrashekar A, et al. Correlates of protection against SARSCoV-2 in rhesus macaques. Nature 2021;590;630-4.

[113] Brocato RL, Principe LM, Kim RK, Zeng X, Williams JA, Liu $\mathrm{Y}$, et al. Disruption of adaptive immunity enhances disease in SARS-CoV-2 infected Syrian hamsters. J Virol 2020;94;e01683-20.

[114] Bieberich F, Vazquez-Lombardi R, Yermanos A, Ehling RA, Mason DM, Wagner B, et al. A single-cell atlas of lymphocyte adaptive immune repertoires and transcriptomes reveals agerelated differences in convalescent COVID-19 patients. bioRxiv 2021 [Preprint].

[115] Neeland MR, Bannister S, Clifford V, Dohle K, Mulholland K, Sutton $\mathrm{P}$, et al. Innate cell profiles during the acute and convalescent phase of SARS-CoV-2 infection in children. Nat Commun $2021 ; 12 ; 1084$.

[116] Nasser R, Pelegrin M, Michaud HA, Plays M, Piechaczyk M, Gros L. Long-lasting protective antiviral immunity induced by passive immunotherapies requires both neutralizing and effector functions of the administered monoclonal antibody. J Virol 2010;84;10169-81.

[117] Focosi D, Maggi F, Mazzetti P, Pistello M. Viral infection neutralization tests: a focus on severe acute respiratory syndrome coronavirus-2 with implications for convalescent plasma therapy. Rev Med Virol 2020;31;e2170.

[118] Khoury DS, Wheatley AK, Ramuta MD, Reynaldi A, Cromer D, Subbarao K, et al. Measuring immunity to SARS-CoV-2 infection: comparing assays and animal models. Nat Rev Immunol 2020;20;727-38.

[119] Schmidt F, Weisblum Y, Muecksch F, Hoffmann HH, Michailidis E, Lorenzi JCC, et al. Measuring SARS-CoV-2 neutralizing antibody activity using pseudotyped and chimeric viruses. J Exp Med 2020;217;e20201181.

[120] Addetia A, Crawford KHD, Dingens A, Zhu H, Roychoudhury P, Huang ML, et al. Neutralizing antibodies correlate with protection from SARS-CoV-2 in humans during a fishery vessel 
outbreak with a high attack rate. J Clin Microbiol 2020;58; e02107-20.

[121] Lv H, Wu NC, Tsang OTY, Yuan M, Perera RAPM, Leung WS, et al. Cross-reactive antibody response between SARS-CoV-2 and SARS-CoV infections. Cell Rep 2020;31;107725.

[122] Schäfer A, Muecksch F, Lorenzi JCC, Leist SR, Cipolla M, Bournazos S, et al. Antibody potency, effector function, and combinations in protection and therapy for SARS-CoV-2 infection in vivo. J Exp Med 2021;218;e20201993.

[123] Klingler J, Weiss S, Itri V, Liu X, Oguntuyo KY, Stevens C, et al. Role of immunoglobulin $\mathrm{M}$ and $\mathrm{A}$ antibodies in the neutralization of severe acute respiratory syndrome coronavirus 2. J Infect Dis 2021;223;957-70.

[124] Harvey RA, Rassen JA, Kabelac CA, Turenne W, Leonard S, Klesh R, et al. Association of SARS-CoV-2 seropositive antibody test with risk of future infection. JAMA Intern Med 2021;e210366 [Epub ahead of print].

[125] Shields AM, Faustini SE, Kristunas CA, Cook AM, Backhouse C, Dunbar L, et al. Longitudinal protection following natural SARS-CoV-2 infection and early vaccine responses: insights from a cohort of community based dental health care professionals. medRxiv 2021 [Preprint].

[126] Bradfute SB, Hurwitz I, Yingling AV, Ye C, Cheng Q, Noonan TP, et al. Severe acute respiratory syndrome coronavirus 2 neutralizing antibody titers in convalescent plasma and recipients in New Mexico: an open treatment study in patients with coronavirus disease 2019. J Infect Dis 2020;222;1620-8.

[127] Yoon HA, Bartash R, Gendlina I, Rivera J, Nakouzi A, Bortz $\mathrm{RH}$, et al. Treatment of severe COVID-19 with convalescent plasma in the Bronx, NYC. medRxiv 2020;2020.12.02.20242909 [Preprint].

[128] Maor Y, Cohen D, Paran N, Israely T, Ezra V, Axelrod O, et al. Compassionate use of convalescent plasma for treatment of moderate and severe pneumonia in COVID-19 patients and association with $\operatorname{IgG}$ antibody levels in donated plasma. EClinicalMedicine 2020;26;100525.

[129] Salazar E, Kuchipudi SV, Christensen PA, Eagar T, Yi X, Zhao P, et al. Convalescent plasma anti-SARS-CoV-2 spike protein ectodomain and receptor-binding domain IgG correlate with virus neutralization. J Clin Invest 2020;130;6728-38.

[130] Walker GJ, Naing Z, Ospina Stella A, Yeang M, Caguicla J, Ramachandran V, et al. SARS coronavirus-2 microneutralisation and commercial serological assays correlated closely for some but not all enzyme immunoassays. Viruses 2021;13;247.

[131] Zhou Y, Liu Z, Li S, Xu W, Zhang Q, Silva IT, et al. Enhancement versus neutralization by SARS-CoV-2 antibodies from a convalescent donor associates with distinct epitopes on the RBD. Cell Rep 2021;34;108699.

[132] Crawford KHD, Dingens AS, Eguia R, Wolf CR, Wilcox N, Logue JK, et al. Dynamics of neutralizing antibody titers in the months after Severe Acute Respiratory Syndrome Coronavirus 2 infection. J Infect Dis 2021;223;197-205.

[133] Harvala H, Robb ML, Watkins N, Ijaz S, Dicks S, Patel M, et al. Convalescent plasma therapy for the treatment of patients with COVID-19: assessment of methods available for antibody detection and their correlation with neutralising antibody levels. Transfus Med 2020 [Epub ahead of print].

[134] Bryan A, Fink SL, Gattuso MA, Pepper G, Chaudhary A, Wener $\mathrm{MH}$, et al. SARS-CoV-2 viral load on admission is associated with 30-day mortality. Open Forum Infect Dis 2020;7;ofaa535.
[135] Benner SE, Patel EU, Laeyendecker O, Pekosz A, Littlefield K, Eby $\mathrm{Y}$, et al. SARS-CoV-2 antibody avidity responses in COVID-19 patients and convalescent plasma donors. J Infect Dis 2020;222;1974-84.

[136] Barnes CO, Jette CA, Abernathy ME, Dam KMA, Esswein SR, Gristick HB, et al. SARS-CoV-2 neutralizing antibody structures inform therapeutic strategies. Nature 2020;588;682-7.

[137] Li Y, Lai DY, Lei Q, Xu ZW, Wang F, Hou H, et al. Systematic evaluation of IgG responses to SARS-CoV-2 spike proteinderived peptides for monitoring COVID-19 patients. Cell Mol Immunol 2021;18;621-31.

[138] Mishra N, Huang X, Joshi S, Guo C, Ng J, Thakkar R, et al. Immunoreactive peptide maps of SARS-CoV-2. Commun Biol 2021;4;225

[139] Polvere I, Voccola S, Cardinale G, Fumi M, Aquila F, Parrella A, et al. A peptide-based assay discriminates individual antibody response to SARS-CoV-2. Genes Dis 2021 [Epub ahead of print].

[140] Hayashi T, Yaegashi N, Konishi I. Effect of RBD (Y453F) mutation in spike glycoprotein of SARS-CoV-2 on neutralizing IgG affinity. medRxiv 2021 [Epub ahead of print].

[141] Grabowski F, Kochańczyk M, Lipniacki T. L18F substrain of SARS-CoV-2 VOC-202012/01 is rapidly spreading in England. medRxiv 2021 [Epub ahead of print].

[142] Abdelnabi R, Boudewijns R, Foo CSY, Seldeslachts L, SanchezFelipe L, Zhang X, et al. Comparative infectivity and pathogenesis of emerging SARS-CoV-2 variants in Syrian hamsters. bioRxiv 2021 [Epub ahead of print].

[143] Graham C, Seow J, Huettner I, Khan H, Kouphou N, Acors S, et al. Impact of the B.1.1.7 variant on neutralizing monoclonal antibodies recognizing diverse epitopes on SARS-CoV-2 Spike. bioRxiv 2021;2021.02.03.429355 [Preprint].

[144] Widera M, Wilhelm A, Hoehl S, Pallas C, Kohmer N, Wolf T, et al. Bamlanivimab does not neutralize two SARS-CoV-2 variants carrying E484K in vitro. medRxiv 2021 [Preprint].

[145] Kuzmina A, Khalaila Y, Voloshin O, Keren-Naus A, Bohehm L, Raviv Y, et al. SARS-CoV-2 escape variants exhibit differential infectivity and neutralization sensitivity to convalescent or post-vaccination sera. medRxiv 2021 [Preprint].

[146] Thomson EC, Rosen LE, Shepherd JG, Spreafico R, da Silva Filipe A, Wojcechowskyj JA, et al. Circulating SARS-CoV-2 spike N439K variants maintain fitness while evading antibody-mediated immunity. Cell 2021;184;1171.e20-87.e20.

[147] Edara VV, Norwood C, Floyd K, Lai L, Davis-Gardner ME, Hudson WH, et al. Reduced binding and neutralization of infection- and vaccine-induced antibodies to the B.1.351 (South African) SARS-CoV-2 variant. bioRxiv 2021;2021.02.20.432046 [Preprint].

[148] Garcia-Beltran WF, Lam EC, St. Denis K, Nitido AD, Garcia $\mathrm{ZH}$, Hauser BM, et al. Multiple SARS-CoV-2 variants escape neutralization by vaccine-induced humoral immunity. medRxiv 2021;2021.02.14.21251704 [Preprint].

[149] Tada T, Dcosta BM, Zhou H, Vaill A, Kazmierski W, Landau NR. Decreased neutralization of SARS-CoV-2 global variants by therapeutic anti-spike protein monoclonal antibodies. bioRxiv 2021;2021.02.18.431897 [Preprint].

[150] Andreano E, Piccini G, Licastro D, Casalino L, Johnson NV, Paciello I, et al. SARS-CoV-2 escape in vitro from a highly neutralizing COVID-19 convalescent plasma. bioRxiv 2020; 2020.12.28.424451 [Preprint]. 
[151] Rathnasinghe R, Jangra S, Cupic A, Martínez-Romero C, Mulder LCF, Kehrer T, et al. The N501Y mutation in SARSCoV-2 spike leads to morbidity in obese and aged mice and is neutralized by convalescent and post-vaccination human sera. medRxiv 2021;2021.01.19.21249592 [Preprint].

[152] Ko SH, Mokhtari EB, Mudvari P, Stein S, Stringham CD, Wagner D, et al. High-throughput, single-copy sequencing reveals SARS-CoV-2 spike variants coincident with mounting humoral immunity during acute COVID-19. bioRxiv 2021;2021.02.21.432184 [Preprint].

[153] Liu Z, VanBlargan LA, Bloyet LM, Rothlauf PW, Chen RE, Stumpf S, et al. Landscape analysis of escape variants identifies SARS-CoV-2 spike mutations that attenuate monoclonal and serum antibody neutralization. bioRxiv 2020;2020.11.06.372037 [Preprint].

[154] Tada T, Dcosta BM, Samanovic-Golden M, Herati RS, Cornelius A, Mulligan MJ, et al. Neutralization of viruses with European, South African, and United States SARS-CoV-2 variant Spike proteins by convalescent sera and BNT162b2 mRNA vaccineelicited antibodies. bioRxiv 2021;2021.02.05.430003 [Preprint].

[155] Hoffmann M, Arora P, Groß R, Seidel A, Hörnich B, Hahn A, et al. SARS-CoV-2 variants B.1.351 and B.1.1.248: escape from therapeutic antibodies and antibodies induced by infection and vaccination. bioRxiv 2021 [Preprint].

[156] Planas D, Bruel T, Grzelak L, Guivel-Benhassine F, Staropoli I, Porrot F, et al. Sensitivity of infectious SARS-CoV-2 B.1.1.7 and B.1.351 variants to neutralizing antibodies. bioRxiv 2021 [Preprint].

[157] Kemp SA, Collier DA, Datir R, Ferreira I, Gayed S, Jahun A, et al. Neutralising antibodies in Spike mediated SARS-CoV-2 adaptation. medRxiv 2020;2020.12.05.20241927 [Preprint].

[158] Diamond M, Chen R, Xie X, Case J, Zhang X, VanBlargan L, et al. SARS-CoV-2 variants show resistance to neutralization by many monoclonal and serum-derived polyclonal antibodies. Res Sq 2021;rs.3.rs-228079 [Preprint].

[159] Li W, Chen C, Drelich A, Martinez DR, Gralinski LE, Sun Z, et al. Rapid identification of a human antibody with high prophylactic and therapeutic efficacy in three animal models of SARSCoV-2 infection. Proc Natl Acad Sci U S A 2020;117;29832-8.

[160] Greaney AJ, Starr TN, Gilchuk P, Zost SJ, Binshtein E, Loes AN, et al. Complete mapping of mutations to the SARS-CoV-2 Spike receptor-binding domain that escape antibody recognition. Cell Host Microbe 2021;29;44.e9-57.e9.

[161] Weisblum Y, Schmidt F, Zhang F, DaSilva J, Poston D, Lorenzi JCC, et al. Escape from neutralizing antibodies by SARS-CoV-2 spike protein variants. Elife 2020;9;e61312.

[162] Wang L, Zhou T, Zhang Y, Yang ES, Schramm CA, Shi W, et al. Antibodies with potent and broad neutralizing activity against antigenically diverse and highly transmissible SARS-CoV-2 variants. bioRxiv 2021;2021.02.25.432969 [Epub ahead of print].

[163] Cerutti G, Rapp M, Guo Y, Bahna F, Bimela J, Reddem ER, et al. Structural basis for accommodation of emerging B.1.351 and B.1.1.7 variants by two potent SARS-CoV-2 neutralizing antibodies. bioRxiv 2021;2021.02.21.432168 [Epub ahead of print].

[164] Bandopadhyay P, D’Rozario R, Lahiri A, Sarif J, Ray Y, Paul SR, et al. Nature and dimensions of the systemic hyper-inflammation and its attenuation by convalescent plasma in severe COVID-19. J Infect Dis 2021;jiab010 [Epub ahead of print].

[165] Arvin AM, Fink K, Schmid MA, Cathcart A, Spreafico R, Havenar-Daughton C, et al. A perspective on potential antibody-dependent enhancement of SARS-CoV-2. Nature 2020;584;353-63.

[166] Yang ZY, Werner HC, Kong WP, Leung K, Traggiai E, Lanzavecchia A, et al. Evasion of antibody neutralization in emerging severe acute respiratory syndrome coronaviruses. Proc Natl Acad Sci U S A 2005;102;797-801.

[167] Lee WS, Wheatley AK, Kent SJ, DeKosky BJ. Antibodydependent enhancement and SARS-CoV-2 vaccines and therapies. Nat Microbiol 2020;5;1185-91.

[168] Zhang C, Wang Y, Zhu Y, Liu C, Gu C, Xu S, et al. Development and structural basis of a two-MAb cocktail for treating SARSCoV-2 infections. Nat Commun 2021;12;264.

[169] Walker LM, Burton DR. Passive immunotherapy of viral infections: 'super-antibodies' enter the fray. Nat Rev Immunol 2018;18;297-308.

[170] Atyeo C, Slein MD, Fischinger S, Burke J, Schäfer A, Leist SR, et al. Dissecting strategies to tune the therapeutic potential of SARS-CoV-2-specific monoclonal antibody CR3022. JCI Insight 2021;6;e143129.

[171] Liu L, Wang P, Nair MS, Yu J, Rapp M, Wang Q, et al. Potent neutralizing antibodies directed to multiple epitopes on SARSCoV-2 spike. Nature 2020;584;450-6.

[172] Zost SJ, Gilchuk P, Case JB, Binshtein E, Chen RE, Nkolola JP, et al. Potently neutralizing and protective human antibodies against SARS-CoV-2. Nature 2020;584;443-9.

[173] Baum A, Ajithdoss D, Copin R, Zhou A, Lanza K, Negron N, et al. REGN-CoV2 antibodies prevent and treat SARS-CoV-2 infection in rhesus macaques and hamsters. Science 2020;370;1110-15.

[174] Imai M, Iwatsuki-Horimoto K, Hatta M, Loeber S, Halfmann PJ, Nakajima N, et al. Syrian hamsters as a small animal model for SARS-CoV-2 infection and countermeasure development. Proc Natl Acad Sci U S A 2020;117;16587-95.

[175] Case JB, Rothlauf PW, Chen RE, Kafai NM, Fox JM, Smith BK, et al. Replication-competent vesicular stomatitis virus vaccine vector protects against SARS-CoV-2-mediated pathogenesis in mice. Cell Host Microbe 2020;28;465.e4-74.e4.

[176] Zheng J, Wong LYR, Li K, Verma AK, Ortiz ME, WohlfordLenane C, et al. COVID-19 treatments and pathogenesis including anosmia in K18-hACE2 mice. Nature 2021;589;603-7.

[177] Cao Y, Su B, Guo X, Sun W, Deng Y, Bao L, et al. Potent neutralizing antibodies against SARS-CoV-2 identified by high-throughput single-cell sequencing of convalescent patients' B cells. Cell 2020;182;73.e16-84.e16.

[178] Rosenfeld R, Noy-Porat T, Mechaly A, Makdasi E, Levy Y, Alcalay R, et al. Post-exposure protection of SARS-CoV-2 lethal infected K18-hACE2 transgenic mice by neutralizing human monoclonal antibody. Nat Commun 2021;12;944.

[179] Winkler ES, Gilchuk P, Yu J, Bailey AL, Chen RE, Zost SJ, et al. Human neutralizing antibodies against SARS-CoV-2 require intact Fc effector functions and monocytes for optimal therapeutic protection. bioRxiv 2020;2020.12.28.424554 [Preprint].

[180] Rogers TF, Zhao F, Huang D, Beutler N, Burns A, He WT, et al. Isolation of potent SARS-CoV-2 neutralizing antibodies and protection from disease in a small animal model. Science 2020;369;956-63.

[181] Gu C, Cao X, Wang Z, Hu X, Yao Y, Zhou Y, et al. A human antibody with blocking activity to RBD proteins of multiple SARS-CoV-2 variants including B.1.351 showed potent prophylactic and therapeutic efficacy against SARS-CoV-2 in rhesus macaques. bioRxiv 2021 [Preprint]. 
[182] De Gasparo R, Pedotti M, Simonelli L, Nickl P, Muecksch F, Lorenzi JCC, et al. Bispecific antibody prevents SARSCoV-2 escape and protects mice from disease. bioRxiv 2021; 2021.01.22.427567 [Preprint].

[183] Le Grand R, Maisonnasse P, Aldon Y, Marc A, Marlin R, Dereuddre-Bosquet $\mathrm{N}$, et al. COVA1-18 neutralizing antibody protects against SARS-CoV-2 in three preclinical models. Res Sq 2021;rs.3.rs-235272 [Preprint].

[184] Chen P, Nirula A, Heller B, Gottlieb RL, Boscia J, Morris J, et al. SARS-CoV-2 neutralizing antibody LYCoV555 in outpatients with covid-19. N Engl J Med 2021;384;229-37.

[185] Gottlieb RL, Nirula A, Chen P, Boscia J, Heller B, Morris J, et al. Effect of bamlanivimab as monotherapy or in combination with etesevimab on viral load in patients with mild to moderate COVID-19: a randomized clinical trial. JAMA 2021;325;632-44.

[186] Schwaiger J, Karbiener M, Aberham C, Farcet MR, Kreil TR. No SARS-CoV-2 neutralization by intravenous immunoglobulins produced from plasma collected before the 2020 pandemic. J Infect Dis 2020;222;1960-4.

[187] Díez JM, Romero C, Vergara-Alert J, Belló-Perez M, Rodon J, Honrubia JM, et al. Cross-neutralization activity against SARS$\mathrm{CoV}-2$ is present in currently available intravenous immunoglobulins. Immunotherapy 2020;12;1247-55.

[188] Díez JM, Romero C, Gajardo R. Currently available intravenous immunoglobulin contains antibodies reacting against severe acute respiratory syndrome coronavirus 2 antigens. Immunotherapy 2020;12;571-6.

[189] Farcet MR, Karbiener M, Schwaiger J, Ilk R, Kreil TR. Rapidly increasing SARS-CoV-2 neutralization by intravenous immunoglobulins produced from plasma collected during the 2020 pandemic. bioRxiv 2021 [Preprint].

[190] Huang C, Fei L, Li W, Xu W, Xie X, Li Q, et al. Efficacy evaluation of intravenous immunoglobulin in non-severe patients with COVID-19: a retrospective cohort study based on propensity score matching. Int J Infect Dis 2021;105;525-31.

[191] Tabarsi P, Barati S, Jamaati H, Haseli S, Marjani M, Moniri A, et al. Evaluating the effects of intravenous immunoglobulin (IVIg) on the management of severe COVID-19 cases: a randomized controlled trial. Int Immunopharmacol 2021;90;107205.

[192] Gharebaghi N, Nejadrahim R, Mousavi SJ, Sadat-Ebrahimi SR, Hajizadeh R. The use of intravenous immunoglobulin gamma for the treatment of severe coronavirus disease 2019: a randomized placebo-controlled double-blind clinical trial. BMC Infect Dis 2020;20;786.

[193] Mohtadi N, Ghaysouri A, Shirazi S, Ansari S, Shafiee E, Bastani E, et al. Recovery of severely ill COVID-19 patients by intravenous immunoglobulin (IVIG) treatment: a case series. Virology 2020;548;1-5.

[194] Xie Y, Cao S, Dong H, Li Q, Chen E, Zhang W, et al. Effect of regular intravenous immunoglobulin therapy on prognosis of severe pneumonia in patients with COVID-19. J Infect 2020;81:318-56.

[195] Farrokhpour M, Rezaie N, Moradi N, Ghaffari Rad F, Izadi S, Azimi $\mathrm{M}$, et al. Infliximab and intravenous gammaglobulin in hospitalized severe COVID-19 patients in intensive care unit. Arch Iran Med 2021;24;139-43.

[196] Feldstein LR, Rose EB, Horwitz SM, Collins JP, Newhams MM, Son MBF, et al. Multisystem inflammatory syndrome in U.S. children and adolescents. N Engl J Med 2020;383;334-46.

[197] Lee PY, Day-Lewis M, Henderson LA, Friedman KG, Lo J, Roberts JE, et al. Distinct clinical and immunological features of SARS-CoV-2-induced multisystem inflammatory syndrome in children. J Clin Invest 2020;130;5942-50.

[198] Ouldali N, Toubiana J, Antona D, Javouhey E, Madhi F, Lorrot $\mathrm{M}$, et al. Association of intravenous immunoglobulins plus methylprednisolone vs immunoglobulins alone with course of fever in multisystem inflammatory syndrome in children. JAMA 2021;325;855-64.

[199] Budhai A, Wu AA, Hall L, Strauss D, Paradiso S, Alberigo J, et al. How did we rapidly implement a convalescent plasma program? Transfusion 2020;60;1348-55.

[200] Flieder T, Vollmer T, Müller B, Dreier J, Fischer B, Knabbe C, et al. Retrospective analysis of 426 donors of a convalescent collective after mild COVID-19. PLoS One 2021;16;e0247665.

[201] Carter JA, Freedenberg AT, Romeiser JL, Talbot LR, Browne NJ, Cosgrove ME, et al. Impact of serological and PCR testing requirements on the selection of COVID-19 convalescent plasma donors. Transfusion 2021 [Epub ahead of print].

[202] Bloch EM, Crowe EP, Tobian AAR. Coronavirus disease 2019 convalescent plasma and the Severe Acute Respiratory Syndrome Coronavirus 2 neutralizing titer. J Infect Dis 2021;223;740-2.

[203] Luchsinger LL, Ransegnola BP, Jin DK, Muecksch F, Weisblum Y, Bao W, et al. Serological assays estimate highly variable SARSCoV-2 neutralizing antibody activity in recovered COVID-19 patients. J Clin Microbiol 2020;58;e02005-20.

[204] Annen K, Morrison TE, DomBourian MG, McCarthy MK, Huey L, Merkel PA, et al. Presence and short-term persistence of SARS-CoV-2 neutralizing antibodies in COVID-19 convalescent plasma donors. Transfusion 2021;61;1148-59.

[205] Gomaa MR, Kandeil A, Mostafa A, Roshdy WH, Kayed AE, Shehata M, et al. Prevalence of severe acute respiratory syndrome coronavirus 2 neutralizing antibodies in Egyptian convalescent plasma donors. Front Microbiol 2020;11;596851.

[206] Andersson MI, Arancibia-Carcamo CV, Auckland K, Baillie JK, Barnes E, Beneke T, et al. SARS-CoV-2 RNA detected in blood products from patients with COVID-19 is not associated with infectious virus. Wellcome Open Res 2020;5;181.

[207] Nomoto H, Kutsuna S, Okuma K, Kuramitsu M, Tezuka K, Ikebe E, et al. No SARS-CoV-2 RNA detected in the convalescent plasma of COVID-19 patients with different disease severity. J Infect Chemother 2021;27;653-5.

[208] Joyner MJ, Wright RS, Fairweather D, Senefeld JW, Bruno KA, Klassen SA, et al. Early safety indicators of COVID-19 convalescent plasma in 5000 patients. J Clin Invest 2020;130;4791-7.

[209] Hacibekiroğlu T, Kalpakçı Y, Genç AC, Hacibekiroğlu İ, Sunu C, Saricaoğlu A, et al. Efficacy of convalescent plasma according to blood groups in COVID-19 patients. Turk J Med Sci 2021;51;45-8.

[210] Xia X, Li K, Wu L, Wang Z, Zhu M, Huang B, et al. Improved clinical symptoms and mortality among patients with severe or critical COVID-19 after convalescent plasma transfusion. Blood 2020;136;755-9.

[211] Libster R, Pérez Marc G, Wappner D, Coviello S, Bianchi A, Braem V, et al. Early high-titer plasma therapy to prevent severe covid-19 in older adults. N Engl J Med 2021;384;610-18.

[212] Zhang B, Liu S, Tan T, Huang W, Dong Y, Chen L, et al. Treatment with convalescent plasma for critically ill patients with severe acute respiratory syndrome coronavirus 2 infection. Chest 2020;158;e9-e13.

[213] Shen C, Wang Z, Zhao F, Yang Y, Li J, Yuan J, et al. Treatment of 5 critically ill patients with COVID-19 with convalescent plasma. JAMA 2020;323;1582-9. 
[214] Ye M, Fu D, Ren Y, Wang F, Wang D, Zhang F, et al. Treatment with convalescent plasma for COVID-19 patients in Wuhan, China. J Med Virol 2020;92;1890-901.

[215] Ahn JY, Sohn Y, Lee SH, Cho Y, Hyun JH, Baek YJ, et al. Use of convalescent plasma therapy in two COVID-19 patients with acute respiratory distress syndrome in Korea. J Korean Med Sci 2020;35;e149.

[216] Olivares-Gazca JC, Priesca-Marín JM, Ojeda-Laguna M, Garces-Eisele J, Soto-Olvera S, Palacios-Alonso A, et al. Infusion of convalescent plasma is associated with clinical improvement in critically ill patients with COVID-19: a pilot study. Rev Invest Clin 2020;72;159-64.

[217] Duan K, Liu B, Li C, Zhang H, Yu T, Qu J, et al. Effectiveness of convalescent plasma therapy in severe COVID-19 patients. Proc Natl Acad Sci U S A 2020;117;9490-6.

[218] Zeng QL, Yu ZJ, Gou JJ, Li GM, Ma SH, Zhang GF, et al. Effect of convalescent plasma therapy on viral shedding and survival in patients with coronavirus disease 2019. J Infect Dis 2020;222;38-43.

[219] Liu M, Chen Z, Dai MY, Yang JH, Chen XB, Chen D, et al. Lessons learned from early compassionate use of convalescent plasma on critically ill patients with covid-19. Transfusion 2020; 60;2210-16.

[220] Naeem S, Gohh R, Bayliss G, Cosgrove C, Farmakiotis D, Merhi B, et al. Successful recovery from COVID-19 in three kidney transplant recipients who received convalescent plasma therapy. Transpl Infect Dis 2020;23;e13451.

[221] Wang M, Yang X, Yang F, Zhu X, Sun Z, Bao P, et al. Convalescent plasma therapy in critically ill coronavirus disease 2019 patients with persistently positive nucleic acid test, case series report. Medicine (Baltimore) 2020;99;e21596.

[222] Zeng H, Wang D, Nie J, Liang H, Gu J, Zhao A, et al. The efficacy assessment of convalescent plasma therapy for COVID-19 patients: a multi-center case series. Signal Transduct Target Ther $2020 ; 5 ; 219$.

[223] Hu X, Hu C, Jiang D, Zuo Q, Li Y, Wang Y, et al. Effectiveness of convalescent plasma therapy for COVID-19 patients in Hunan, China. Dose Response 2020;18;1559325820979921.

[224] Ji F, Liu W, Hao DA, Cheng J, Tong XC, Hao JG, et al. Use of convalescent plasma therapy in eight individuals with mild COVID-19. New Microbes New Infect 2021;39;100814.

[225] Fung M, Nambiar A, Pandey S, Aldrich JM, Teraoka J, Freise C, et al. Treatment of immunocompromised COVID-19 patients with convalescent plasma. Transpl Infect Dis 2020;e13477 [Epub ahead of print].

[226] Jin H, Reed JC, Liu STH, Ho HE, Lopes JP, Ramsey NB, et al. Three patients with X-linked agammaglobulinemia hospitalized for COVID-19 improved with convalescent plasma. J Allergy Clin Immunol Pract 2020;8;3594.e3-6.e3.

[227] Diorio C, Anderson EM, McNerney KO, Goodwin EC, Chase JC, Bolton MJ, et al. Convalescent plasma for pediatric patients with SARS-CoV-2-associated acute respiratory distress syndrome. Pediatr Blood Cancer 2020;67; 228693.

[228] Schwartz SP, Thompson P, Smith M, Lercher DM, Rimland CA, Bartelt L, et al. Convalescent plasma therapy in four critically ill pediatric patients with coronavirus disease 2019: a case series. Crit Care Explor 2020;2;e0237.

[229] Erkurt MA, Sarici A, Berber İ, Kuku İ, Kaya E, Özgül M. Life-saving effect of convalescent plasma treatment in covid-19 disease: clinical trial from eastern Anatolia. Transfus Apher Sci 2020;59;102867.
[230] Rahman F, Liu STH, Taimur S, Jacobs S, Sullivan T, Dunn D, et al. Treatment with convalescent plasma in solid organ transplant recipients with COVID-19: experience at large transplant center in New York City. Clin Transplant 2020;34;e14089.

[231] Tremblay D, Seah C, Schneider T, Bhalla S, Feld J, Naymagon L, et al. Convalescent plasma for the treatment of severe COVID-19 infection in cancer patients. Cancer Med 2020;9;8571-8.

[232] Huang S, Shen C, Xia C, Huang X, Fu Y, Tian L. A retrospective study on the effects of convalescent plasma therapy in 24 patients diagnosed with COVID-19 pneumonia in February and March 2020 at 2 centers in Wuhan, China. Med Sci Monit 2020;26; e928755.

[233] Chen S, Lu C, Li P, Wang L, Wang H, Yang Q, et al. [Effectiveness of convalescent plasma for treatment of coronavirus disease 2019 patients]. Zhonghua Wei Zhong Bing Ji Jiu Yi Xue 2020;32;1293-8 [Article in Chinese].

[234] Pal P, Ibrahim M, Niu A, Zwezdaryk KJ, Tatje E, Robinson WR, et al. Safety and efficacy of COVID-19 convalescent plasma in severe pulmonary disease: a report of 17 patients. Transfus Med 2020 [Epub ahead of print].

[235] Xiao K, Lin Y, Fan Z, Wen Y, Huang H, Wang M, et al. Effect of transfusion convalescent recovery plasma in patients with coronavirus disease 2019. Zhong Nan Da Xue Xue Bao Yi Xue Ban 2020;45;565-70 [Article in English, Chinese].

[236] Gemici A, Bilgen H, Erdoğan C, Kansu A, Olmuşçelik O, Beköz HS, et al. A single center cohort of 40 severe COVID-19 patients who were treated with convalescent plasma. Turk J Med Sci 2020;50;1781-5.

[237] Hueso T, Pouderoux C, Péré H, Beaumont AL, Raillon LA, Ader F, et al. Convalescent plasma therapy for B-cell-depleted patients with protracted COVID-19. Blood 2020;136;2290-5.

[238] Cantore I, Valente P. Convalescent plasma from COVID-19 patients enhances intensive care unit survival rate: a preliminary report. Transfus Apher Sci 2020;59;102848.

[239] González SE, Regairaz L, Ferrando NS, González Martinez VV, Salazar MR, Estenssoro E. [Convalescent plasma therapy in COVID-19 patients, in the Province of Buenos Aires]. Medicina (B Aires) 2020;80;417-24 [Article in Spanish].

[240] Joyner MJ, Bruno KA, Klassen SA, Kunze KL, Johnson PW, Lesser ER, et al. Safety update: COVID-19 convalescent plasma in 20,000 hospitalized patients. Mayo Clin Proc 2020;95;1888-97.

[241] Nguyen FT, van den Akker T, Lally K, Lam H, Lenskaya V, Liu STH, et al. Transfusion reactions associated with COVID-19 convalescent plasma therapy for SARS-CoV-2. Transfusion 2021;61;78-93.

[242] Wu Y, Hong K, Ruan L, Yang X, Zhang J, Xu J, et al. Patients with prolonged positivity of SARS-CoV-2 RNA benefit from convalescent plasma therapy: a retrospective study. Virol Sin 2020;35;768-75.

[243] Joyner MJ, Senefeld JW, Klassen SA, Mills JR, Johnson PW, Theel ES, et al. Effect of convalescent plasma on mortality among hospitalized patients with COVID-19: initial three-month experience. medRxiv 2020;2020.08.12.20169359 [Preprint].

[244] Perotti C, Baldanti F, Bruno R, Del Fante C, Seminari E, Casari S, et al. Mortality reduction in 46 severe Covid-19 patients treated with hyperimmune plasma. A proof of concept single arm multicenter trial. Haematologica 2020;105;2834-40.

[245] Salazar E, Perez KK, Ashraf M, Chen J, Castillo B, Christensen PA, et al. Treatment of coronavirus disease 2019 (COVID-19) patients with convalescent plasma. Am J Pathol 2020;190;1680-90. 
[246] Balcells ME, Rojas L, Le Corre N, Martínez-Valdebenito C, Ceballos ME, Ferrés M, et al. Early anti-SARS-CoV-2 convalescent plasma in patients admitted for COVID-19: a randomized Phase II clinical trial. medRxiv 2020 [Preprint].

[247] Ibrahim D, Dulipsingh L, Zapatka L, Eadie R, Crowell R, Williams K, et al. Factors associated with good patient outcomes following convalescent plasma in COVID-19: a prospective phase II clinical trial. Infect Dis Ther 2020;9;913-26.

[248] Hartman WR, Hess AS, Connor JP. Hospitalized COVID-19 patients treated with convalescent plasma in a mid-size city in the Midwest. Transl Med Commun 2020;5;17.

[249] González SE, Regairaz L, Salazar MR, Ferrando NS, González Martinez VV, Carrera Ramos PM, et al. Timing of convalescent plasma administration and 28-day mortality for COVID-19 pneumonia. medRxiv 2021 [Preprint].

[250] Janaka SK, Hartman W, Mou H, Farzan M, Stramer SL, Goodhue $\mathrm{E}$, et al. Donor anti-Spike immunity is related to recipient recovery and can predict the efficacy of convalescent plasma units. medRxiv 2021 [Preprint].

[251] Abolghasemi H, Eshghi P, Cheraghali AM, Fooladi AAI, Bolouki Moghaddam F, Imanizadeh S, et al. Clinical efficacy of convalescent plasma for treatment of COVID-19 infections: results of a multicenter clinical study. Transfus Apher Sci 2020;59;102875.

[252] Salazar E, Christensen PA, Graviss EA, Nguyen DT, Castillo B, Chen J, et al. Treatment of coronavirus disease 2019 patients with convalescent plasma reveals a signal of significantly decreased mortality. Am J Pathol 2020;190;2290-303.

[253] Altuntas F, Ata N, Yigenoglu TN, Basc1 S, Dal MS, Korkmaz S, et al. Convalescent plasma therapy in patients with COVID-19. Transfus Apher Sci 2021;60;102955.

[254] Liu STH, Lin HM, Baine I, Wajnberg A, Gumprecht JP, Rahman F, et al. Convalescent plasma treatment of severe COVID-19: a propensity score-matched control study. Nat Med 2020;26;1708-13.

[255] Rogers R, Shehadeh F, Mylona EK, Rich J, Neill M, TouzardRomo F, et al. Convalescent plasma for patients with severe COVID-19: a matched cohort study. Clin Infect Dis 2020; ciaa1548 [Epub ahead of print].

[256] Salazar E, Christensen PA, Graviss EA, Nguyen DT, Castillo B, Chen J, et al. Significantly decreased mortality in a large cohort of coronavirus disease 2019 (COVID-19) patients transfused early with convalescent plasma containing high-titer anti-severe acute respiratory syndrome coronavirus 2 (SARS-CoV-2) Spike protein IgG. Am J Pathol 2021;191;90-107.

[257] Hegerova L, Gooley TA, Sweerus KA, Maree C, Bailey N, Bailey M, et al. Use of convalescent plasma in hospitalized patients with COVID-19: case series. Blood 2020;136;759-62.

[258] Omrani AS, Zaqout A, Baiou A, Daghfal J, Elkum N, Alattar RA, et al. Convalescent plasma for the treatment of patients with severe coronavirus disease 2019: a preliminary report. J Med Virol 2021;93;1678-86.

[259] Alsharidah S, Ayed M, Ameen RM, Alhuraish F, Rouheldeen NA, Alshammari FR, et al. COVID-19 convalescent plasma treatment of moderate and severe cases of SARS-CoV-2 infection: a multicenter interventional study. Int J Infect Dis 2021;103;439-46.

[260] Dai W, Wu J, Li T, Shen J, Pang R, Luo T, et al. Clinical outcomes for COVID-19 patients with diabetes mellitus treated with convalescent plasma transfusion in Wuhan, China. J Med Virol 2021;93;2321-31.
[261] Moniuszko-Malinowska A, Czupryna P, Zarębska-Michaluk D, Tomasiewicz K, Pancewicz S, Rorat M, et al. Convalescent plasma transfusion for the treatment of COVID-19-experience from Poland: a multicenter study. J Clin Med 2021;10;28.

[262] Sturek JM, Thomas TA, Gorham JD, Sheppard CA, Raymond AE, Petros De Guex K, et al. Convalescent plasma for preventing critical illness in COVID-19: a phase 2 trial and immune profile. medRxiv 2021;2021.02.16.21251849 [Preprint].

[263] Sostin OV, Rajapakse P, Cruser B, Wakefield D, Cruser D, Petrini J. A matched cohort study of convalescent plasma therapy for COVID-19. J Clin Apher 2021 [Epub ahead of print].

[264] Mesina FZ, Mangahas CG, Gatchalian EM, Ariola-Ramos MS, Torres RP. Use of convalescent plasma therapy among hospitalized coronavirus disease 2019 (COVID-19) patients: a singlecenter experience. medRxiv 2021 [Epub ahead of print].

[265] Klapholz M, Pentakota SR, Zertuche JP, McKenna M, Roque W, Forsberg $\mathrm{M}$, et al. Matched cohort study of convalescent COVID-19 plasma treatment in severely or life threateningly ill COVID-19 patients. Open Forum Infect Dis 2021;8;ofab001.

[266] AlShehry N, Zaidi SZA, AlAskar A, Al Odayani A, Alotaibi JM, AlSagheir A, et al. Safety and efficacy of convalescent plasma for severe COVID-19: interim report of a multicenter phase II study from Saudi Arabia. Saudi J Med Med Sci 2021;9;16-23.

[267] Li L, Zhang W, Hu Y, Tong X, Zheng S, Yang J, et al. Effect of convalescent plasma therapy on time to clinical improvement in patients with severe and life-threatening COVID-19: a randomized clinical trial. JAMA 2020;324;460-70.

[268] Agarwal A, Mukherjee A, Kumar G, Chatterjee P, Bhatnagar T, Malhotra $\mathrm{P}$, et al. Convalescent plasma in the management of moderate COVID-19 in adults in India: open label phase II multicenter randomized controlled trial (PLACID Trial). BMJ 2020;371;m3939.

[269] Avendaño-Solà C, Ramos-Martínez A, Muñez-Rubio E, RuizAntorán B, Malo de Molina R, Torres F, et al. Convalescent plasma for COVID-19: a multicenter, randomized clinical trial. medRxiv 2020 [Preprint].

[270] Rasheed AM, Fatak DF, Hashim HA, Maulood MF, Kabah KK, Almusawi YA, et al. The therapeutic potential of convalescent plasma therapy on treating critically-ill COVID-19 patients residing in respiratory care units in hospitals in Baghdad, Iraq. Infez Med 2020;28;357-66.

[271] Gharbharan A, Jordans CCE, Guertsvankessel C, den Hollander JG, Karim F, Mollema FPN, et al. Convalescent plasma for COVID-19. A randomized clinical trial. medRxiv 2020 [Preprint].

[272] Skrip L, Derra K, Kaboré M, Noori N, Gansané A, Valéa I, et al. Clinical management and mortality among COVID-19 cases in sub-Saharan Africa: a retrospective study from Burkina Faso and simulated case analysis. Int J Infect Dis 2020;101;194-200.

[273] Jaiswal V, Nasa P, Raouf M, Gupta M, Dewedar H, Mohammad H, et al. Therapeutic plasma exchange followed by convalescent plasma transfusion in critical COVID-19-an exploratory study. Int J Infect Dis 2021;102;332-4.

[274] Selzman CH, Tonna JE, Pierce J, Vargas C, Skidmore C, Lewis G, et al. A pilot trial of human amniotic fluid for the treatment of COVID-19. BMC Res Notes 2021;14;32.

[275] Ryman JT, Meibohm B. Pharmacokinetics of monoclonal antibodies. CPT Pharmacometrics Syst Pharmacol 2017;6;576-88.

[276] Dirks NL, Meibohm B. Population pharmacokinetics of therapeutic monoclonal antibodies. Clin Pharmacokinet 2010;49;633-59. 
[277] Melamed IR, Borte M, Trawnicek L, Kobayashi AL, Kobayashi RH, Knutsen A, et al. Pharmacokinetics of a novel human intravenous immunoglobulin $10 \%$ in patients with primary immunodeficiency diseases: analysis of a phase III, multicenter, prospective, open-label study. Eur J Pharm Sci 2018;118;80-6.

[278] Koleba T, Ensom MHH. Pharmacokinetics of intravenous immunoglobulin: a systematic review. Pharmacotherapy 2006; $26 ; 813-27$

[279] Hahn RG, Lyons G. The half-life of infusion fluids: an educational review. Eur J Anaesthesiol 2016;33;475-82.
[280] Fleck A, Raines G, Hawker F, Trotter J, Wallace PI, Ledingham IM, et al. Increased vascular permeability: a major cause of hypoalbuminemia in disease and injury. Lancet $1985 ; 325 ; 781-4$.

[281] Pathak EB. Convalescent plasma is ineffective for COVID-19. BMJ 2020;371;m4072.

[282] Martinez DR, Schaefer A, Leist SR, Gully K, Feng JY, Bunyan E, et al. Early therapy with remdesivir and antibody combinations improves COVID-19 disease in mice. bioRxiv 2021;2021.01.27.428478 [Preprint]. 